\title{
Use of Polyphenols as Modulators of Food Allergies. From Chemistry to Biological Implications
}

\author{
Catarina Bessa, Telmo Francisco, Ricardo Dias, Nuno Mateus, Victor de Freitas and \\ Rosa Pérez-Gregorio*
}

Associated Laboratory for Green Chemistry of the Network of Chemistry and Technology (LAQV-REQUIMTE) Departamento de Química e Bioquímica, Faculdade de Ciências da Universidade do Porto, Porto, Portugal

The multifactorial process of aging predisposes humans to infections and inflammatory disorders, thus affecting their quality of life and longevity. Given this reality, the need to increase the consumption of bioactive compounds, like dietary polyphenols emerges in our daily basis mostly due to their health related effects in slowing-down the incidence of chronic and degenerative diseases and even food allergy, which has been growing rapidly in prevalence currently affecting $5 \%$ of adults and $8 \%$ of children. Polyphenols

OPEN ACCESS

Edited by:

Andrea Gomez-Zavaglia, National University of La Plata, Argentina

Reviewed by: Guadalupe Virginia Nevárez-Moorillón, Autonomous University of Chihuahua, Mexico Maria Inês Dias, Centro de Investigação de Montanha (C/MO), Portugal

*Correspondence:

Rosa Pérez-Gregorio maria.gregorio@fc.up.pt

Specialty section:

This article was submitted to

Sustainable Food Processing, a section of the journal Frontiers in Sustainable Food Systems

Received: 30 October 2020 Accepted: 10 May 2021 Published: 08 July 2021

Citation:

Bessa C, Francisco T, Dias $R$ Mateus N, Freitas Vd and Pérez-Gregorio R (2021) Use of

Polyphenols as Modulators of Food Allergies. From Chemistry to Biological Implications.

Front. Sustain. Food Syst. 5:623611. doi: 10.3389/fsufs.2021.623611 embrace a large family of secondary metabolites from plant-derived foods and food wastes and are considerable of interest since they have attracted special attention over the years because of their reported anti-inflammatory and antimicrobial properties along with their high antioxidant capacity. These compounds are claimed as nutraceuticals with protective effect in offsetting oxidant species over-genesis in normal cells, and with the potential ability to stop or reverse oxidative stress-related diseases. Plant-derived foods represent a substantive portion of human diet containing a significant amount of structurally diverse polyphenols. There is a need to understand the polyphenolic composition of plant-derived foods mainly because of its chemistry, which discloses the bioactivity of a plant extract. However, the lack of standardized methods for analysis and other difficulties associated to the nature and distribution of plant polyphenols leads to a high variability of available data. Furthermore, there is still a gap in the understanding of polyphenols bioavailability and pharmacokinetics, which clearly difficult the settlement of the intake needed to observe health outcomes. Many efforts have been made to provide highly sensitive and selective analytical methods for the extraction (liquid-liquid; solid-liquid; supercritical-fluid), separation (spectrophotometric methods) and structural identification (chromatographic techniques, NMR spectroscopy, MS spectrometry) of phenolic and polyphenolic compounds present in these extracts. Liquid chromatography coupled to mass spectrometry (LC-MS) has been a fundamental technique in this area of research, not only for the determination of this family of compounds in food matrices, but also for the characterization and identification of new polyphenols classified with nutraceutical interest. This review summarizes the nature, distribution and main sources of polyphenols, analytical methods from extraction to characterization to further evaluate the health effects toward immune reactions to food.

Keywords: plant polyphenols, polyphenols characterization, polyphenols intake, protein/polyphenols interaction, food allergy, polyphenols from wastes 


\section{PAST, PRESENT AND FUTURE IN POLYPHENOLS UPCYCLE}

In the last years, the agricultural and food sector has been challenged with a continuous growing demand for nutritious foods, owing to the dramatic increase of world's population and changes in human dietary habits (Mathys et al., 2018). At present, it is estimated that more than 800 million people around the globe are still suffering from hunger, even though recent numbers indicate that almost one third of the food destined for human feeding is lost or wasted (Garcia-herrero et al., 2019). The agricultural sector generates, by now, $\sim 140$ billion tons of organic wastes per year (Dedousi et al., 2017; Zuin and Ramin, 2018; Gullón et al., 2020). In an attempt to control such trend, the agri-food sector is now starting to implement cleaner, and sustainable, production strategies that seek to combine process efficiency to food quality and safety (Esparza et al., 2020). As a result, agro-industrial wastes such as stalks, leaves, bark, roots, straw residues, bagasse, wood and seeds that were once seen as unimportant materials and, as a consequence, discarded, are revealing themselves to be an outstanding source of bioactive and health-promoting compounds (Dedousi et al., 2017; Panzella et al., 2020).

The consumption of plant-based foods, including not only fruits and vegetables, seeds or cereals but also derived foodstuffs and beverages, has been claimed to be beneficial for human health by the scientific community and general public (Atta ur and Iqbal Choudhary, 2015). Consumers are progressively interested in foods that not only meets nutritional requirements but also improves physical performance and promote health and well-being while reducing environmental stress (Tresserrarimbau et al., 2014; Gowd et al., 2019; Serino and Salazar, 2019; de Araújo et al., 2020). This challenge has led the agri-food sector to develop novel processes capable of recovering waste byproducts generated during collection, processing, and storage of food items (Zhu et al., 2020). Regarding this, a growing interest has emerged in the valorization of these agri-food by-products in order to improve the sustainability of the food industry and reduce environmental problems involved in the management of these residues (Barba et al., 2017; Zuin and Ramin, 2018). Apart from their functionality as a source of energy, agri-food by-products should also be considered as value-added residues due to their chemical heterogeneity and content of bioactive compounds for subsequent applications in pharmaceutical, food and cosmetic sectors (Piccolella et al., 2019). These applications may range from functional food ingredients to nutraceuticals or even for obtaining other valuable bio-products, contributing not only for a sustainable and circular economy but also for the implementation of zero waste politics (Mirabella et al., 2014; Esparza et al., 2020).

Among all bioactive compounds found in agro-industrial wastes, polyphenols have become an emerging field of interest and research in several areas, not only for nutritionists but also for food scientists (Perez-Gregorio and Simal-Gandara, 2017; Santhakumar et al., 2018; Dias et al., 2020). Polyphenols, organic bioactive compounds known as secondary metabolites of plants are of considerable physiological and morphological importance in plants. In the last century, several clinical and epidemiological studies revealed that they possess a strong antioxidant capacity and anti-inflammatory properties that could have preventive or/and therapeutic effects for degenerative diseases, cardiovascular diseases, neurodegenerative disorders, cancer, obesity and food allergy (Kobernick and Burks, 2016; Mrduljaš et al., 2017; Cory et al., 2018; Gullón et al., 2020). Given these health benefits, the determination and characterization of polyphenols in foods to evaluate their bioavailability and bioactivity is becoming one of the most important research areas in food analysis (Lucci et al., 2017; Perez-Gregorio and Simal-Gandara, 2017). Conducting and adequate polyphenols extraction and characterization is crucial to further correlate the health outcomes. Indeed, significant efforts have been made in recent years to develop extraction methods for polyphenol recovery either directly from food products or from agri-food wastes (Domínguez-Rodríguez et al., 2017; Pinela et al., 2017; Panja, 2018; Routray and Orsat, 2019; Altinok et al., 2020; Esposito et al., 2020; Gómez-mejía et al., 2020). However, these techniques present several issues related to polyphenol stability during extraction process and to solvent toxicity, raising concerns about environmental damage and human health (Kelly et al., 2019; Yu et al., 2020). Regarding this, in the last decade, a demand for new extraction techniques has increased searching for higher extraction efficiency while reducing the extraction time, but also considering the ecological footprint of extraction procedures (Maroun et al., 2018; Panja, 2018; Piccolella et al., 2018; Kelly et al., 2019; Ballesteros-Vivas et al., 2020; PimentelMoral et al., 2020). Moreover, the analysis and characterization of polyphenols in food samples is quite complex not only due to their high diversity in plant based-foods and beverages but also because of the high complexity of food matrices (Manach et al., 2004; Lucci et al., 2017; Vuolo et al., 2018). Given the relevance of the subject, this review summarizes the main extraction methods as well as the main analytical techniques employed in the polyphenols characterization to further use these polyphenols as modulators of immune reactions to food. The biological mechanisms as well as application to use polyphenols to prevent food allergies was adopted through a nutritional point of view in a circular economy approach.

\section{POLYPHENOLS IN AGRICULTURAL BYPRODUCTS AND FOOD WASTE: CHEMISTRY AND OCCURRENCE}

Valorization of agri-food wastes has become a major priority to improve the sustainability of the food chain, minimizing environmental impacts and contributing to a circular economy based on zero waste policies (Rodriguez et al., 2020). In order to obtain potentially marketable polyphenols from agri-food wastes, sustainable, environmentally friendly and feasible lowcost processes need to be developed (Papaioannou et al., 2020). Understanding the chemistry and nature of polyphenols is the key for these purposes. They are present in almost all foods from plant origin such as fruits, vegetables and beverages, and include more than 8,000 structural variants (Belščak-Cvitanović 
et al., 2018). Polyphenols are plant secondary metabolites, synthesized through different pathways such as the shikimate or phenylpropanoid as well as pentose phosphate one. They are generally involved in plant defense and protection (Vuolo et al., 2019), contribute to the growth and reproduction of plants and have an important role in the organoleptic properties of vegetables and fruits (de Araújo et al., 2020). Polyphenols are classified into two main groups depending on their structural features such as the number of phenol rings and structural elements that links these rings to one another: non-flavonoids (phenolic acids, stilbenes and lignans) and flavonoids (flavones, flavonols, flavanols, flavanones, isoflavones, and anthocyanins) (Libro et al., 2016). Polyphenols classification is summarized in Table 1 and the chemistry and nature of each group are described as follows:

\section{Non-flavonoids Phenolic Acids}

Phenolic acids are broadly found all over the plant kingdom and can be divided into benzoic and cinnamic acids (Stalikas, 2007). These non-flavonoid compounds represent almost 30\% of total dietary polyphenols (Belščak-Cvitanović et al., 2018). Benzoic acid derivatives are characterized by one carboxylic group $(\mathrm{COOH})$. The most common ones are gallic, protocatechuic, vanillic and $\rho$-hydroxybenzoic acids. Usually, the amount of benzoic acids found in edible plants is not high, but in certain red fruits and onions they can reach several tens of milligrams per kilogram of fresh weight (Lucci et al., 2017). The most common cinnamic acid derivatives are $\rho$-coumaric (the most abundant isomer), $\rho$-hydroxycinnamic, sinapic, caffeic and ferulic acids. Despite their occurrence in nature as both cis and trans isomers, in plants, cinnamic acids appears mainly as trans isomers (Manach et al., 2004; de Araújo et al., 2020). Furthermore, phenolic acids should appear in nature free or conjugated to sugars and low-molecular-mass components.

\section{Stilbenes}

Stilbenes are produced by plants in response to injury and infections, but very low quantities are found in the human diet (Manach et al., 2004; Belščak-Cvitanović et al., 2018). Only resveratrol is considered important to human health, being grape skins, red wine, peanuts, blueberries and cranberries the main sources of this compound. Pterostilbene, a compound chemically related to resveratrol, is also found in grapes and blueberries; due to high antioxidant capacity, it is also considered important to human health (Mrduljaš et al., 2017).

\section{Lignans}

Lignans are composed by two phenylpropane units. This small class of compounds are mainly found in linseed, which predominantly encloses secoisolariciresinol. Lower concentrations of lignans can also be found in grains and cereals such as oat, wheat, rye and barley; some fruits such as strawberries or apricots and certain vegetables from the Brassica genera like cabbage or broccoli (Calderón-Oliver and Ponce-Alquicira, 2018). Despite being a small family, it should be noticed that the intake of food containing lignans has been linked to prevention of cardiovascular diseases and cancers (Durazzo et al., 2019). Lignin is a random oxidative polymerization of lignans and have been considered as the most naturally abundant and important biopolymer substance in plant cell walls, exceeded only by cellulose.

\section{Flavonoids}

Flavonoids are widely distributed in plants, especially in fruits and vegetables. They have been extensively studied over the past few years due to their important role in synthesis of enzymes and vitamins, in minimizing lipid peroxidation and in influencing the organoleptic characteristics of foods (Del Rio et al., 2013; Belščak-Cvitanović et al., 2018; Durazzo et al., 2019). Structurally, they consist in an oxygenated heterocycle (C) linked to two aromatic rings ( $\mathrm{A}$ and $\mathrm{B}$ ) with a three-carbon bridge. This 15carbon skeleton structure is usually referred to as C6-C3-C6. Flavonoids can be divided in six subclasses according with the degree of oxidation of the $\mathrm{C}$ ring and the position and number of hydroxyl groups: flavanols, flavones, flavonols, anthocyanidins, flavanones, and isoflavones (Durazzo et al., 2019). Each group contains a huge number of structural variations due to chemical substitutions such as glycosylation, acylation or alkylation (Birt and Jeffery, 2013; Calderón-Oliver and Ponce-Alquicira, 2018). The content of flavonoids in fruits and vegetables depend on several factors, including genetic factors, climatic and agronomic conditions or ripening. Usually, flavonoids are found in plants under the form of glycosides. Despite their high bioactivity, their bioavailability when ingested is very low (Vuolo et al., 2018).

\section{Flavonols}

Flavonols are one of the most abundant flavonoids in plant kingdom. They are usually glycosylated with glucose or rhamnose residues but other mono or di-saccharides may also be involved (El Gharras, 2009; Del Rio et al., 2013). Quercetin, kaempferol, and myricetin are the main flavonols found in vegetables such as broccoli, onions, kale and tomatoes and fruits like apricots, cranberries, grapes and apples (Lucci et al., 2017).

\section{Flavones}

In general, flavones are not found in fruits and vegetables, but in aromatic herbs such as parsley or even celery (Manach et al., 2004). Structurally, they can occur in hydroxylated, methylated, -glycosylated and/or alkylated forms (Del Rio et al., 2013). Examples of flavones include luteolin, apigenin, tangeritin, chrysin, scutellarein, 6-hydroxyflavone, wogonin, and baicalein. Some of these compounds are mainly found in citrus fruits such as tangerine and orange and are highly hydrophobic (El Gharras, 2009).

\section{Isoflavones}

Isoflavones have been identified almost exclusively in leguminous and grain plants such as soya and soybeans. Its main representatives are daidzein, genistein, glycitein, and biochanin A. These flavonoids have an estrogen-like structure, and thus, are classified as phytoestrogens. They have the potential to be used as natural alternatives to traditional hormone therapies (Lucci et al., 2017; Durazzo et al., 2019). 
TABLE 1 | Polyphenols classification.

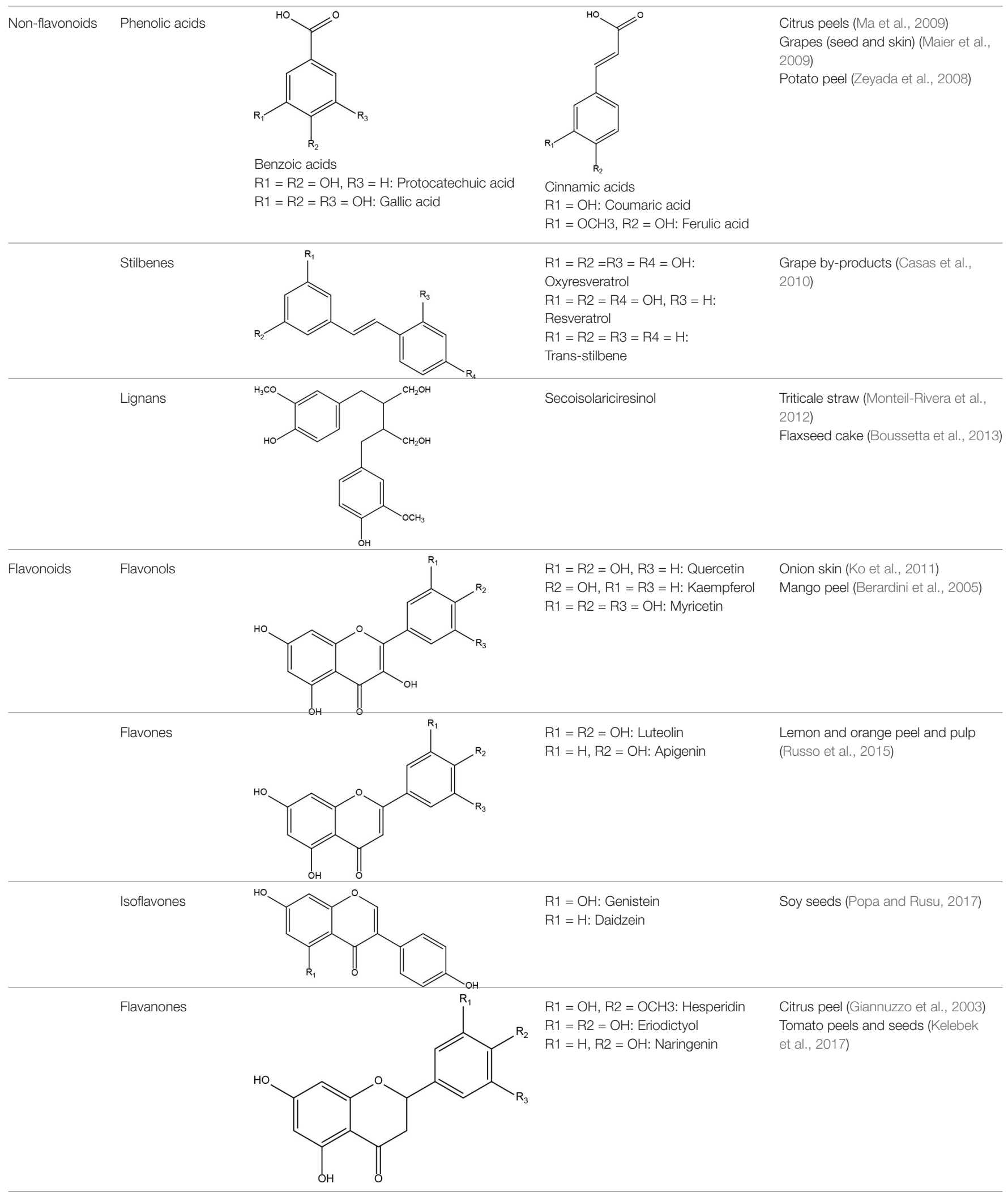




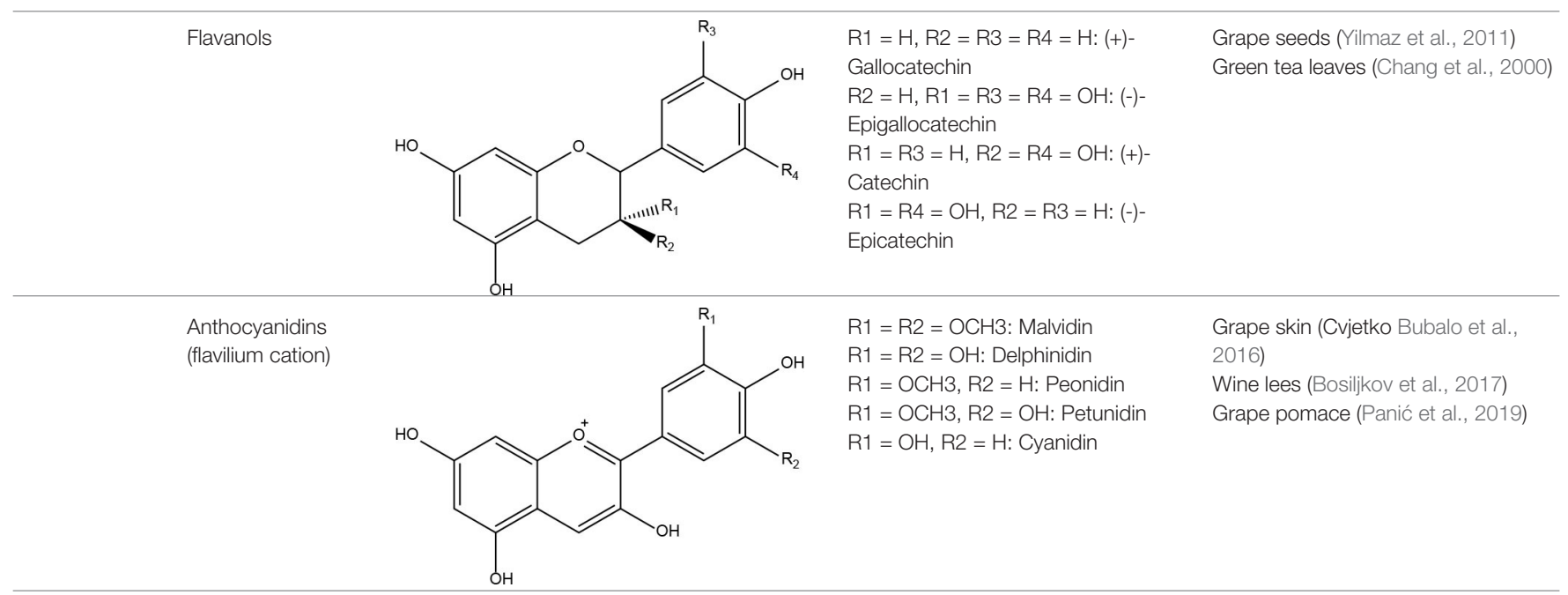

\section{Flavanones}

Flavanones are highly present in citrus fruits but can also be found at lower concentrations in tomatoes, spices and in some aromatic plants such as mint (El Gharras, 2009). Usually, this group of polyphenols is bound to one or two sugars moieties, and less frequently found as aglycones (Del Rio et al., 2013). Solid parts of citrus fruits have a very high flavanone content; they contain up to five times as much as orange juice serving. Generally, flavanones include aglycones such as hesperetin, naringenin, eriodictyol, and their glycosidic forms, namely naringin, neohesperidin, narirutin, and hesperidin (Lucci et al., 2017; Calderón-Oliver and Ponce-Alquicira, 2018).

\section{Anthocyanidins}

Anthocyanidins are responsible for providing color to plant tissues such as stems, leaves, roots, flowers and fruits. The chemistry of anthocyanins is a little bit complex varying according with the $\mathrm{pH}$. Their color range from red to purple and blue depending on the species in equilibrium (Manach et al., 2004). Besides their role as water-soluble pigments, anthocyanidins also contribute to taste modeling astringent sensations, even though they are odorless and flavorless. Anthocyanidins are considered one of the most important flavonoids classes and can be found in colored fruits like berries, cherries, red cabbage, eggplant, red onion, and red wine (Lucci et al., 2017; Calderón-Oliver and Ponce-Alquicira, 2018). Due to their instability in the aglycone form, they are usually present in fruits and vegetables in the form of glycosides (anthocyanins), such as malvidin, delphinidin, peonidin, petunidin, cyanidin, among others (Del Rio et al., 2013). In this form, anthocyanins in fruits and vegetables provide resistance to light, $\mathrm{pH}$ and oxidation (Mrduljaš et al., 2017).

\section{Flavanols}

Flavanols are the most complex class of flavonoids, ranging from simple monomers to oligomers and polymers (also known as condensed tannins or proanthocyanidins). Contrary to other flavonoids, flavanols do not appear in plant-based foods and beverages glycosylated (Del Rio et al., 2013). Monomeric flavanols such as catechin and epicatechin can be found in high concentrations in red wine, green tea and chocolate, whereas epigallocatechin, gallocatechin and epigallocatechin gallate are found in certain seeds, grains or grapes, and in green tea (Manach et al., 2004; El Gharras, 2009). Proanthocyanidins made of catechin units are named procyanidins. Usually these compounds are the main responsible for the astringency of some fruits and beverages are the most ubiquitous type of proanthocyanidins found in plants (Mrduljaš et al., 2017).

Despite the great structural diversity among polyphenols (Figure 1), little isolated compounds or extracts have been assayed as modulators of food allergy. Indeed, related information is summarized in Table 2. As shown, different mechanisms were proposed, as further in-detail discussed, but little is known regarding the structure-activity relationship. Both polyphenol-rich extracts as well as isolated compounds were tested. A higher anti-allergic activity was generally observed in extracts instead of pure compounds (Tokura et al., 2005; Shim et al., 2009a; Zuercher et al., 2010). Likewise, flavonoid aglycones appeared to present a stronger histamine release-inhibitory activity and cytotoxicity than glycosides. Among flavonoids, it has been highlighted that flavonols require a $3-\mathrm{OH}$ group for inhibitory activity while a 3-O-glycoside group may sterically hinder the active site of the aglycone. At the same, the presence of a 4'-hydroxyl group enhanced the activity of flavones while c-glycosilated flavones are less active. Overall, the glycosylation and methylation patterns was probed as able to influence the immunomodulatory effect of polyphenols in flavonols and flavones. However, the activity of anthocyanins, as well as the polymerization grade in flavan-3ols or structural key motifs in non-flavonoid compounds have not been studied jet.

\section{Innovative Green Extraction Technologies Applied to Agri-Food By-Products}

Sample treatment is considered a crucial step before the extraction, isolation and characterization of compounds. The 


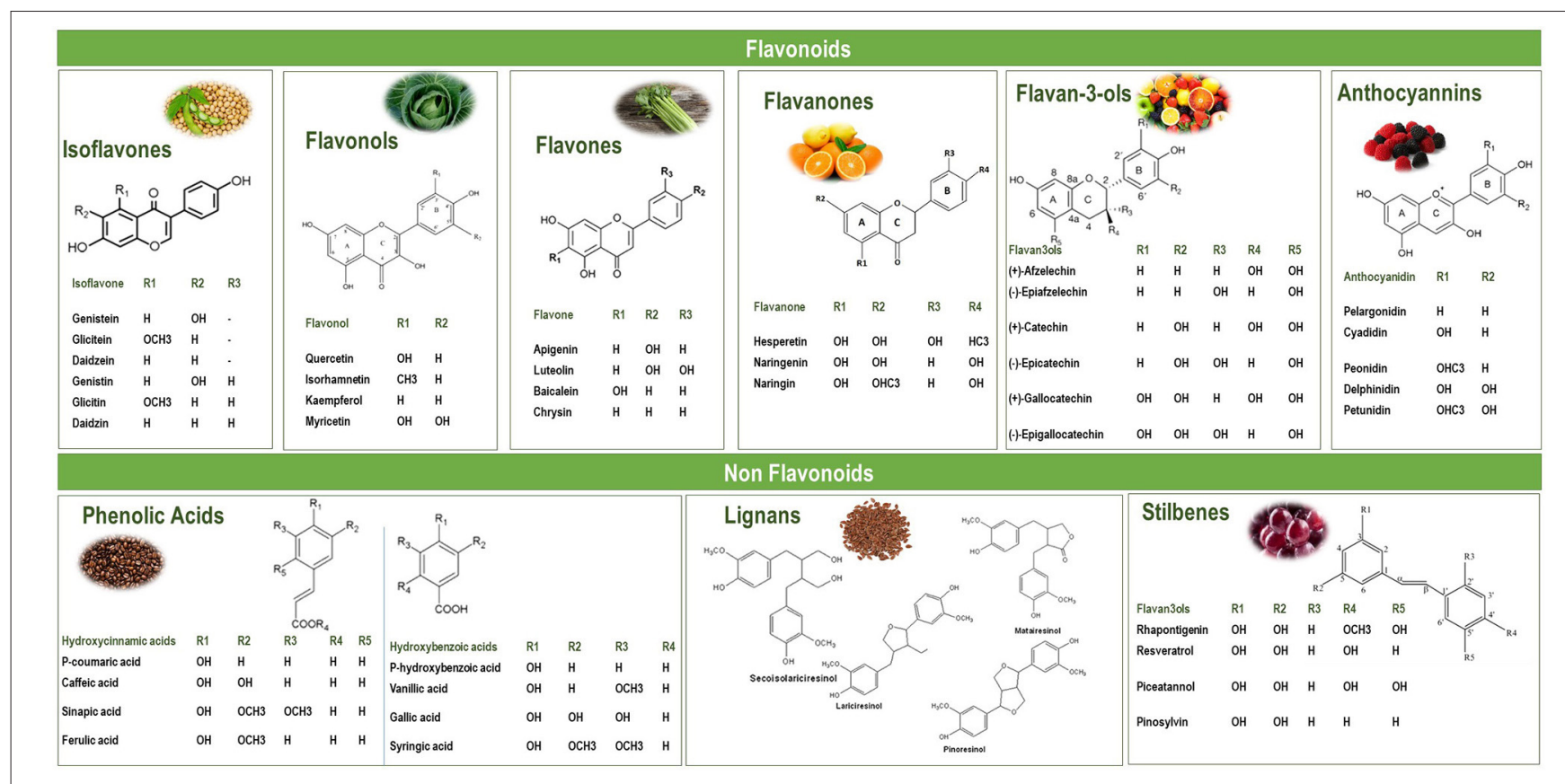

FIGURE 1 | Diversity in polyphenols structures and families.

major objectives of this process are to improve sample stability, to increase extraction efficiency, to remove impurities and to convert the analytes into a suitable form for detection, separation or quantification (Kontogianni, 2014; Pyrzynska and Sentkowska, 2019).

Solid samples usually follow pretreatment processes such as milling, grinding or sieving and homogenization. The latter are generally preceded by air drying or freezing with liquid nitrogen and freeze-drying in order to prevent or stop enzymatic activities. On the other hand, liquid samples can be treated by filtration, centrifugation, and purification before extraction (Khoddami et al., 2013; Kontogianni, 2014). Usually, solid phase extraction (SPE) is used as a pre-cleaning step to remove interfering elements from samples, allowing polyphenol isolation and determination (Pyrzynska and Sentkowska, 2019). The most used material for SPE is chemically bonded silica, typically with a C8 or C18 organic group, but other type of resins such as Sephadex LH-20, polyamide and amberlite have also been used to remove interfering compounds or to concentrate analytes (Kontogianni, 2014).

The extraction of polyphenols from agri-food by-products and food-based products is fundamental to obtain the desired compounds for further analytical characterizations (Kontogianni, 2014; Chemat et al., 2019). As already referred, extraction techniques have been classified into conventional techniques and green technologies (Pimentel-Moral et al., 2020). The conventional extraction methods include solid-liquid extraction and liquid-liquid extraction, using heat and/or mixing with organic solvents such as acetone, hexane, methanol, ethanol or ethyl acetate. These extraction methods depend on several factors such as pressure, extraction time and $\mathrm{pH}$ (Louis et al., 2019; Gullón et al., 2020) and presents some difficulties associated with the thermal degradation of target compounds due to the high temperature employed (Pimentel-Moral et al., 2020). Considering this, great efforts have been made to develop emerging extraction techniques based in clean and sustainable practices focused on minimizing the use of solvents, energy and materials that are unsafe to human health and to the environment (Zuin and Ramin, 2018; Chemat et al., 2019). Recent technologies have been recently developed in order to control undesirable effects on the bioactivity and structure of polyphenols during extraction processes, such as microwaveassisted extraction (MAE), pressurized liquid extraction (PLE), ultrasound-assisted extraction (UAE) and supercritical fluid extraction (SFE) among others (Mourtzinos and Goula, 2019; Kumar, 2020). These greener extraction techniques are known for their short extraction time, reduced volume of organic and unsafe solvents and high efficiency with lower energy consumption when compared to conventional extraction methods (Belwal et al., 2018).

\section{Ultrasound-Assisted Extraction}

This extraction method is based on the creation of cavitation bubbles when ultrasound waves pass through the extraction system, creating alternate decompression and compression cycles, which result in the compression and expansion of bubbles. When this bubbles grow too large to be contained by the surface tension force, they collapse, thus creating localized high pressure and temperature zones that cause plant tissues rupture and improve the release of intracellular compounds into the solvent (Magaton et al., 2020; Pimentel-Moral et al., 2020). This extraction method can be affected by several factors such as 
TABLE 2 | Polyphenols assayed and mechanisms probed as modulators of food allergies.

\begin{tabular}{|c|c|c|c|c|}
\hline Polyphenol & Experimental study & Biological action & Food Allergy & References \\
\hline $\begin{array}{l}\text { Epigallocatechin } \\
\text { gallate }\end{array}$ & $\begin{array}{l}\text { Protein-polyphenol } \\
\text { complexation }\end{array}$ & Conformational changes & $\begin{array}{l}\text { Milk allergy } \\
\text { (lactalbumin) }\end{array}$ & $\begin{array}{l}\text { Wang et al., 2014; } \\
\text { Al-Hanish et al., } 2016\end{array}$ \\
\hline $\begin{array}{l}\text { Epigallocatechin } \\
\text { gallate }\end{array}$ & $\begin{array}{l}\text { Protein-polyphenol } \\
\text { complexation }\end{array}$ & Conformational changes & Peanut allergy & Vesic et al., 2015 \\
\hline $\begin{array}{l}\text { Apple extract } \\
\text { Pomactiv HFV and } \\
\text { quercetin }\end{array}$ & Mouse model & $\begin{array}{l}\text { Impair the presentation } \\
\text { to dendritic cells }\end{array}$ & Ovalbumin model & Zuercher et al., 2010 \\
\hline $\begin{array}{l}\text { Red wine and coffee } \\
\text { polyphenols }\end{array}$ & In vivo-gut microbiota & Increase bacterioides & $\begin{array}{l}\text { Inflammation } \\
\text { biomarkers-rhinitis } \\
\text { allergic asthma }\end{array}$ & Singh et al., 2017 \\
\hline $\begin{array}{l}\text { Fruit, seed, wine and } \\
\text { tea polyphenols }\end{array}$ & In vivo-gut microbiota & Decrease clostridium & $\begin{array}{l}\text { Inflammation } \\
\text { biomarkers-general } \\
\text { health status }\end{array}$ & Singh et al., 2017 \\
\hline $\begin{array}{l}\text { Apple crude extract, } \\
\text { apple condensed } \\
\text { tannins, epicatechin, } \\
\text { chlorogenic acid, } \\
\text { phlorizin }\end{array}$ & $\begin{array}{l}\text { Mast cell degranulation } \\
\text { in vitro (RBL-2H3 cells } \\
\text { and rat mast cells) }\end{array}$ & Histamine release & $\begin{array}{l}\text { Allergy universal } \\
\text { model }\end{array}$ & Kanda et al., 1998 \\
\hline $\begin{array}{l}\text { Psidium guajava } \\
\text { extracts }\end{array}$ & $\begin{array}{l}\text { Mouse model-C57BL/6 } \\
\text { mice }\end{array}$ & Inhibition Treg cells & - & Seo et al., 2005 \\
\hline $\begin{array}{l}\text { Polyphenol-enriched } \\
\text { apple extracts }\end{array}$ & $\begin{array}{l}\text { Mast cell degranulation } \\
\text { in vitro }\end{array}$ & $\begin{array}{l}\text { Binding between } \\
\text { polyphenols and lgE - } \\
\text { FCeRI }\end{array}$ & $\begin{array}{l}\text { Allergy universal } \\
\text { model }\end{array}$ & Tokura et al., 2005 \\
\hline $\begin{array}{l}\text { Ferulic acid, } \\
\text { chlorogenic acid, } \\
\text { caffeic acid }\end{array}$ & Western blot & IgE binding & Peanut allergy & $\begin{array}{l}\text { Chung and } \\
\text { Champagne, 2009b }\end{array}$ \\
\hline Ecklonia cava extract & $\begin{array}{l}\text { Mast cell degranulation } \\
\text { in vitro (KU812F cells) }\end{array}$ & $\begin{array}{l}\text { Binding between } \\
\text { polyphenols and lgE - } \\
\text { FCeRI }\end{array}$ & $\begin{array}{l}\text { Allergy universal } \\
\text { model }\end{array}$ & Shim et al., 2009a \\
\hline $\begin{array}{l}\text { Perilla frutescens } \\
\text { extract, apigenin }\end{array}$ & $\begin{array}{l}\text { In vivo-BALB/c mice } \\
\text { Mast cell degranulation } \\
\text { in vitro - RBL- } 2 \mathrm{H} 3 \text { cells }\end{array}$ & $\begin{array}{l}\text { Mast cell degranulation } \\
\text { Histamine release } \\
\text { FceRl cross-linking }\end{array}$ & $\begin{array}{l}\text { Japanese cedar } \\
\text { pollinosis }\end{array}$ & Kamei et al., 2017 \\
\hline Green tea polyphenols & $\begin{array}{l}\text { Protein-polyphenol } \\
\text { complexation }\end{array}$ & Digestion process & $\begin{array}{l}\text { Egg allergy } \\
\text { (ovalbumin and } \\
\text { lysozyme) }\end{array}$ & Shen et al., 2014 \\
\hline Ferulic acid & Mouse model & Inflammation biomarkers & Atopic dermatitis & Zhou et al., 2020 \\
\hline Cocoa enriched diet & In vivo-gut microbiota & Inflammation biomarkers & - & $\begin{array}{l}\text { Camps-Bossacoma } \\
\text { et al., } 2019\end{array}$ \\
\hline Polyphenol-rich diet & In vivo-gut microbiota & Metabolic parameters & - & $\begin{array}{l}\text { Singh et al., 2011; Mine } \\
\text { et al., } 2020\end{array}$ \\
\hline $\begin{array}{l}\text { Green tea, black tea, } \\
\text { oolong tea }\end{array}$ & $\begin{array}{l}\text { In vivo-gut microbiota } \\
\text { Polyphenols } \\
\text { Bioavailability (caco-2 } \\
\text { cell model) }\end{array}$ & $\begin{array}{l}\text { Metabolic parameters } \\
\text { Epithelium transport } \\
\text { Gut bacteria proliferation }\end{array}$ & - & Sun et al., 2018 \\
\hline
\end{tabular}

ultrasound power and solvent composition or extraction time and temperature (Vieira da Silva et al., 2016). Usually, two types of equipment are employed, namely, ultrasonic probe and water bath system fitted with horn transducers (Panja, 2018). $\mathrm{UAE}$ is a green and efficient way to increase mass transfer, requiring reduced quantities of solvent and without specific solvent requirements (Dedousi et al., 2017; Contreras et al., 2020). Additionally, this extraction method is considered a rapid and sustainable alternative to conventional methods and it can be scaled up to industrial scales (Briones-Labarca et al., 2015; Meregalli et al., 2020; Saifullah et al., 2020).

\section{Microwave-Assisted Extraction}

Microwave-assisted extraction (MAE) is an emerging technology, that consists in the insertion of solvent and sample in a closed vessel using radiation to raise the temperature of the solvent above its boiling point. This heating process causes the rupture of the cell membrane, increasing polyphenol extraction (Kelly et al., 2019). Many aspects may affect this extraction method such as extraction time or temperature, solvent, sample-to-solvent ratio and microwave power. The capacity to absorb microwave radiation is the key factor when choosing the solvents to be used for extraction. This extraction process is quick, uses lower 
solvent volume, can be performed in the absence of light and allows the extraction of polyphenols with similar yields when compared to conventional methods. Therefore, MAE is a useful methodology to extract and concentrate polyphenols in a single step (Mourtzinos and Goula, 2019; Kumar, 2020).

\section{Pressurized Liquid Extraction}

PLE occurs inside a closed and inert reaction vessel at high pressures (3.3-20.3 MPa), allowing the use of temperatures well above the boiling point of some common solvents $\left(40-200^{\circ} \mathrm{C}\right)$. This improves the solubility and mass transfer of compounds, consequently raising the extraction efficiency (Ballesteros-Vivas et al., 2020; Pimentel-Moral et al., 2020). Matrix properties, type of solvent, extraction time and temperature are fundamental factors that determine PLE efficiency. When water is used as a solvent, PLE is commonly called pressurized hot water extraction, being this process entirely environmentally friendly and economically viable. Therefore, PLE is considered an energy saving methodology and environmentally safe as the most used solvents are water and ethanol, which are considered GRAS (Generally recognized as Safe) solvents (Kelly et al., 2019).

\section{Supercritical Fluid Extraction}

This extraction method is based on the use of gases, mostly $\mathrm{CO}_{2}$, above or near critical temperature and pressure (Panzella et al., 2020). In these conditions, fluids behave like a single phase, displaying the properties of both liquid and gas at the same time. Fluid disperses into the solid matrix like a gas and dissolves target compounds like a liquid (Maroun et al., 2018). This extraction process is highly dependent on temperature and pressure. $\mathrm{CO}_{2}$ is the most attractive fluid for SFE since it is non-toxic, nonflammable, chemically inert, cheap and widely (Kelly et al., 2019). The addition of a co-solvent can modify the polarity of the $\mathrm{scCO}_{2}$ allowing the extraction of more polar molecules (Panzella et al., 2020). Usually, SFE uses extraction temperatures between 30 and $70^{\circ} \mathrm{C}$. Also, this extraction process can be scaled up to an industrial size (Carabias-Martínez et al., 2005; Herrero et al., 2010). Although this technology involves easy operation, low production costs and high extraction efficiency, there has to be a significant investment in equipment need to be made to make the process viable (Wang et al., 2016).

Despite the great diversity in extraction methods little is known regarding the impact in the biological activity. A recent study reveals that solvent extracts had a remarkable influence on polyphenols characterization and activity, confirming the strong correlation between phytochemical constituents and antioxidant activities (Bouasla et al., 2021). However, most studies focused in analyzing the anti-allergic activities of polyphenols have not deep in the extracts characterization and effects of extraction methods. In the face of the priority to obtain sustainable agri-food systems, is mandatory to evaluate the gap between the extraction methods and their impact in bioactive compounds characterization and further biological effect.

\section{CHARACTERIZATION OF POLYPHENOLS}

The analysis of polyphenols in complex extracts requires efficient separation methods prior to their detection. Despite a high number of investigations, the separation and quantification of polyphenols in food matrices remain difficult, particularly if there are polyphenols from different groups (Naczk and Shahidi, 2004; Khoddami et al., 2013). High performance liquid chromatography (HPLC) has been the main technique to separate, characterize, and quantify polyphenols in the last 20 years. Some other relevant techniques include spectrophotometric assays (Kontogianni, 2014).

\section{Spectrophotometric Assays}

The Folin-Denis and Folin-Ciocalteu methods are relatively simple and have been commonly used to measure total phenolics in foods and plant materials for many years. The theoretical basis behind these methods are based on the chemical reduction of tungsten and molybdenum-containing salts, whose products have a broad light absorption around $760 \mathrm{~nm}$ (Khoddami et al., 2013). Besides the low cost and simplicity of these methods, the results are prone to overestimations because the Folin reagent reacts not only with polyphenols but also with compounds with reducing groups like sugars. These methods are suitable to obtain a global estimation of total phenolic compounds; yet, they do not offer a quantitative measurement of individual compounds. Therefore, more precise and exact methods such as chromatographic techniques are needed for qualitative and quantitative analyses (Naczk and Shahidi, 2004; DomínguezRodríguez et al., 2017).

\section{Chromatographic Assays: High Performance Liquid Chromatographic}

High performance liquid chromatographic techniques are now most widely used for both separation and quantitation of polyphenols (Naczk and Shahidi, 2004). This technique has not only the capacity to analyze all components of interest simultaneously but also their derivatives and degradation products. The chromatographic conditions of the HPLC methods include the use of a reversed-phase $\mathrm{C} 18$ column or alternatively a C8, a UV-Vis diode array detector and a binary solvent system containing acidified water (solvent A) and a polar organic solvent (solvent B) (Ignat et al., 2011). Generally, the most used organic solvents are acetonitrile and methanol. A common strategy to suppress the ionization of phenolic hydroxyl groups is to acidify solvents using acetic or formic acid, which also improves the resolution and reproducibility of the retention characteristics (Stalikas, 2007). Chromatographic separation depends mainly on the molecular weight, stereochemistry, polarity of the analytes and on matrix complexity. Reverse phase (RP) HPLC-DAD is the mostly used tool for the separation and determination of polyphenols. However, because the UV spectra of polyphenols are often very similar to each other, one needs to apply modern high-performance chromatographic techniques combined with instrumental analysis like NMR an MS for structural identifications (Ignat et al., 2011; Khoddami et al., 2013; Dzah et al., 2020).

Mass spectrometry coupled to liquid chromatography is a very useful analytical technique not only for quantitative analysis but also to elucidate the chemical structure of known and unknown compounds (Khoddami et al., 2013). This technique relies on the ionization of chemical compounds to generate charged 
molecules or molecular fragments whose mass-to-charge ratios are subsequently measured. Analysis with MS detector can be performed with different types of ionization in the ion source such as electrospray ionization (ESI) and atmospheric pressure chemical ionization (APCI) (Yang et al., 2009). ESI is the most used interface in LC-MS configurations, because it combines efficient separation capabilities of HPLC with the exact structural characterization of MS. Several scanning modes can be used to give additional structural information such as fragmentation of the pseudo molecular ion, selected ion monitoring (SIM), selected reaction monitoring (SRM) or multiple reaction monitoring (MRM) (Pyrzynska and Sentkowska, 2019). In order to improve the sensitivity and minimize the matrix effects, several MS/MS parameters can be optimized such as the capillary voltage, collision energy and ion mode (López-fernández et al., 2020). Therefore, LC-MS is considered as a standard method for the identification and characterization of polyphenols and presents several advantages such as selectivity, rapid method development, cost effectiveness, among others (Kumar, 2017).

\section{Nuclear Magnetic Resonance Spectroscopy}

Nuclear magnetic resonance (NMR) is a complementary spectroscopic technique that provides complete structural elucidation of polyphenols either extracted from complex mixtures or without any previous sample preparation (Ajila et al., 2011). Several techniques have been employed to analyze polyphenols including ${ }^{1} \mathrm{H}$ NMR and ${ }^{13} \mathrm{C}$ NMR, twodimensional homonuclear $\left(2 \mathrm{D}{ }^{1} \mathrm{H}-{ }^{1} \mathrm{H}\right)$, heteronuclear chemical shift correlation NMR (C-H HECTOR), correlated NMR spectroscopy (COZY), totally correlated NMR spectroscopy (TOCSY), rotating frame of reference (ROESY) and nuclear Overhauser effect in the laboratory frame (NOESY) (Naczk and Shahidi, 2006; Ye et al., 2015).

NMR instrument coupled to other analytical instruments such as HPLC, UV-Vis and MS to achieve an on-line separation and structural elucidation is a useful tool when target compounds are difficult to isolate or are unstable (Ye et al., 2015). Although expensive, NMR has many advantages over other techniques such as accuracy, precision, simplicity of the sample preparation, among others (Kontogianni, 2014).

In the last years, a huge number of analytical advances and applications have been applied for food analyses. Yet, there is still several concerns that need to be solved in this field of research. Overall, developing appropriate methods for the proper extraction, purification and characterization of polyphenols is necessary to achieve higher accuracy in the obtained results for each type of analytes.

\section{USE OF POLYPHENOLS AS MODULATORS OF IMMUNE REACTIONS TO FOOD. THE CASE OF FOOD ALLERGY}

On the basis of cross-sectional, prospective and intervention studies concerning polyphenols and human health and wellbeing, several experimental papers in the literature have tried to understand the molecular mechanisms behind their bioactivity. Moreover, in vitro studies have reported the potential of polyphenols to modulate several diseases such as cancer, cardiovascular diseases or metabolic disorders (Fernandes et al., 2017). Polyphenols have been demonstrated to inhibit cell proliferation in cancer studies, improve insulin secretion, stimulate vasodilatation and influence cell signaling and function (Del Rio et al., 2010). But what about food allergies? Are polyphenols able to influence the process? Food allergy (FA) is defined as "an adverse health effect arising from a specific immune response that occurs reproducibly on exposure to a given food" (Panel et al., 2010). Noteworthy, the prevalence of FA has increased over the past decades; nevertheless, therapeutic options remain limited. A better understanding of the key nutritional mechanisms involved in such immune responses will likely be vital for disease prevention and development of new therapies. Scientific knowledge has therefore to be improved to establish the basis for new treatments and prevention methods (Sicherer and Sampson, 2018). Hence, the effect of polyphenols as natural attenuators of FA has to be studied. This section summarizes the scientific evidences and future challenges in this field.

\section{Nature and Prevalence of Food Allergy}

The prevalence of FA is affected by lifestyle and food availability, particularly in developed western countries (Prescott et al., 2013; Tang and Mullins, 2017; De Martinis et al., 2019). In general, FA are more common in children than in adults due to the immaturity of their immune system. The great majority of affected children "outgrow" FA with age (Prioult and NaglerAnderson, 2005; Prescott et al., 2013; De Martinis et al., 2019). Additionally, studies are showing that the incidence of FA among elderly is increasing with aging all around the world (Ventura et al., 2010; Mohrenschlager and Ring, 2011).

The immune responses caused by FA can be broadly categorized in two major types: Immunoglobulin $\mathrm{E}$ ( $\operatorname{IgE}$ )mediated disorders and non-IgE mediated food allergies (though a mix between $\operatorname{IgE}$ and non-IgE mechanisms is also common) (Sicherer and Sampson, 2009; Anvari et al., 2019). In IgE mediated FA, the allergen activates a rapid $\mathrm{T}$ helper (Th) 2 cell response characterized by Th2 cell proliferation, production of pro-allergic cytokines, interleukin-4 (IL-4), IL-5, and IL-13; and the release of allergic mediators, such as histamine and $\beta$-hexosaminidase, by effector cells (mast cells and basophils) (Anvari et al., 2019). In IgE-mediated reactions the symptoms occur shortly after food ingestion and may result in a potentially life-threatening allergic reaction that affects multiple organs (anaphylaxis) (Anvari et al., 2019). Conversely, non-IgE dependent reactions are typically restricted to the gastrointestinal tract and include a wide spectrum of chronic disorders, where allergen-specific T cells are thought to have a prominent role (Yu et al., 2016). However, non IgE dependent food allergies are more difficult to diagnose, and they generally reverse in infancy, usually before the age of 6 years (Connors et al., 2018).

The most common diagnostic procedures for FA are skin prick tests (SPTs) and serum food-specific IgE tests. However, there are numerous diagnostic procedures whose employment is 
chosen based on the medical history and physical examination (Sicherer and Sampson, 2010). The standard of care of FA includes strict dietary elimination of the allergen and ready access to injectable epinephrine to avoid anaphylaxis reactions (Bird et al., 2015); however, no active, definitive therapeutic options exist for food-allergic patients (Muraro et al., 2014; Sicherer and Sampson, 2018). Although the mechanisms underlying the development of FA are still under study, FA appears to be the direct result of a breakdown in oral tolerance, defined as the unresponsiveness of the immune system after food antigen exposure (Yu et al., 2016). Oral tolerance is an active process that occurs at the gut-associated lymphoid tissue (GALT) and is mediated predominately by regulatory $\mathrm{T}$ cells ( $\mathrm{Yu}$ et al., 2016). The lack of tolerance initiates when the food antigen crosses the gut epithelial barrier and is processed by antigen presenting cells (APCs) into peptides, which are displayed on APCs surface to be recognized by antigen-specific Th cells. In the presence of inflammatory stimuli, Th cells differentiate into allergen-specific Th2 cells that orchestrate allergic sensitization mechanisms. Accordingly, sensitization mediated by Th2 cells includes the differentiation of B cells into plasmocytes, which secret antigen-specific systemic IgEs. Then, after the re-exposure to the food antigen, IgEs bind the surface receptor FceRI expressed in mast cells and basophils. This IgE-Fc\&RI interaction promotes mast cells and basophils degranulation as well as the release of allergen-induced cytokines (IL-4 and IL-13) (Yu et al., 2016).

Currently, therapeutic approaches to FA are focused on oral food challenges (OFCs) that is to say, modulating the immune response to allergens promoting the induction of oral tolerance (Muraro et al., 2014; Sicherer and Sampson, 2018). Although OFCs are promising, tolerance to allergens has to be induced, posing a danger to patients (e.g., anaphylaxis). Overall, to date the guidelines for controlling a FA are to avoid allergens and be prepared in case of exposure, for example with epinephrine to counteract a potential fatal reaction (Lieberman et al., 2015). Hence, further research must be performed in order to find safer alternatives to prevent or control FA epidemic.

\section{Dietary Effects in Food Allergy Incidence-Microbiota Role}

Dietary factors influence gut microbiota and consequently the immune system (Chistiakov et al., 2015). Not surprisingly, this crosstalk between gut bacteria and immune cells was found to be closely related to the development of allergic disorders. Commensal microbiota colonizes mucosal surfaces, such as respiratory tracts, skin, vagina, and gastrointestinal tracts. These microorganisms are in symbiosis with the host, and influence nutrient absorption, resistance to pathogens, immune defense, and tissue repair (Hong et al., 2017). In the intestine, these bacteria have important immunoregulatory properties, as they provide a large variety of harmless antigens that continuously stimulate intestinal immune cells to be tolerant, not only to molecules produced by commensal bacteria, but also to exogenous proteins derived from food (Chistiakov et al., 2015). Moreover, microbiota derived signals have a direct impact on
$\mathrm{T}$ cell differentiation, with some favoring the regulatory $\mathrm{T}$ cell subset, which is vital for the maintenance of the intestinal homeostasis (Arroyo Hornero et al., 2020).

Notwithstanding, some factors including the mode of delivery (van Nimwegen et al., 2011; Mitselou et al., 2018), use of antibiotics (Hirsch et al., 2017), a western diet (Myles, 2014), and improved hygiene patterns (Prioult and Nagler-Anderson, 2005; Hong et al., 2017), can lead to dysbiosis, which is characterized by changes in the microbial communities and their metabolic reactions. Altogether, this imbalance can diminish the mucosal immune tolerance to commensal bacteria and food antigens leading to a less protection against allergic diseases (Pascal et al., 2018).

There are a few studies relating the presence of allergies with changes in bacterial ecology and diversity early in life (Prioult and Nagler-Anderson, 2005; Hong et al., 2017). Furthermore, different diets lead to different microbial compositions, as shown in Figure 2. Protein, fats, carbohydrates, probiotics, and polyphenols induce changes in commensal microbiota, interfering with immune responses. The intake of animal protein induces the increase concentration of bile-tolerant microorganisms and decrease butyrate-producing bacteria. Carbohydrates suppress the growth of butyrate-producing bacteria and increase the anaerobic bacteria concentration. The saturated fat ingestion contributes to increase the number of anaerobic bacteria. Probiotics contain beneficial living microorganisms to balance the gut microbiota (Singh et al., 2017). Moreover, probiotics and polyphenols increase lactic-acid bacteria concentration.

The study of different diets seems to be important to understand how it interferes with gut microbiota. Western and Mediterranean diets are very popular worldwide and differ widely. Table 3 compares the two types of diet. The association between the mostly consumed components in these diets and their interference in gut microbiota, allows to conclude that Western diet contributes to the reduction of flora diversity, particularly of the beneficial species, whereas Mediterranean diet provides a more varied and balanced microbiota. Accordingly, considering the influence of intestinal microbiota on immune responses, the adoption of Mediterranean diet provides greater protection against allergic diseases (Singh et al., 2017).

Proving the importance of adopting a varied diet to maintain a balanced flora (Figure 2), it is also necessary to relate dietary habits with the digestive processes and how this can influence the development of FA (Ortega, 2006; Pali-Schöll et al., 2018). Food intake determines the composition of microbiota and therefore, the maintenance of a healthy physiological epithelial barrier and function and, consequently, oral tolerance (Tappenden and Deutsch, 2007). The effect of several diet components in FA development has been highlighted. Epidemiologic studies suggest that selenium; zinc; vitamins $\mathrm{A}, \mathrm{C}, \mathrm{D}$, and $\mathrm{E}$ deficiencies, low fiber consumption and high fat intake may be associated with the development of allergic disorders (Kamer et al., 2012; Allen et al., 2013; Jonsson et al., 2016; Tan et al., 2016). Fruits and vegetables are important sources of dietary antioxidants, mainly polyphenols, which have been widely described as containing antiallergic properties (Kanda et al., 1998; Gruber et al., 2004; 


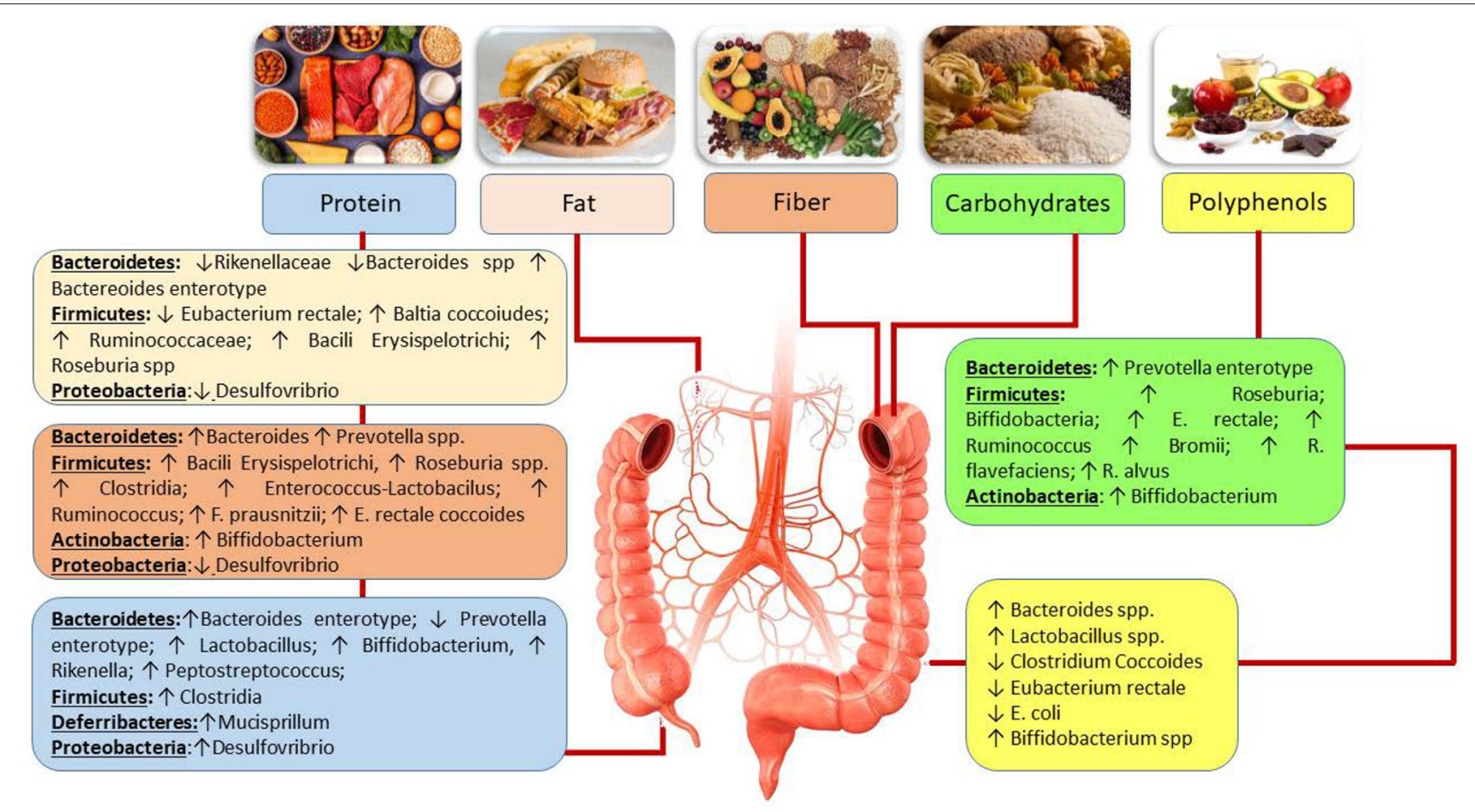

FIGURE 2 | Influence of different food intakes in commensal microbiota composition.

TABLE 3 | Comparison between Mediterranean diet and Western diet.

\begin{tabular}{|c|c|c|c|c|c|}
\hline & & Western diet intake & $\begin{array}{l}\text { Mediterranean diet } \\
\text { uptake }\end{array}$ & Food sources examples & References \\
\hline \multirow[t]{3}{*}{ Food macronutrients } & Lipids (saturated) & High & Moderate & Fast-food, animal oil, butter & Mirmiran et al., 2021 \\
\hline & $\begin{array}{l}\text { Carbohydrates } \\
\text { (sugar) }\end{array}$ & High & Moderate & $\begin{array}{l}\text { Bread, cookies, } \\
\text { ultraprocessed food }\end{array}$ & $\begin{array}{l}\text { Gómez-Donoso et al., } \\
2021\end{array}$ \\
\hline & Proteins & High & Moderate & Meat, fish, legumes & Altomare et al., 2013 \\
\hline Food micronutrients & Vitamins & Low & High & Fruits and vegetables & $\begin{array}{l}\text { De Pergola and } \\
\text { D'Alessandro, } 2018\end{array}$ \\
\hline \multirow[t]{5}{*}{ Bioactive compounds } & Polyphenols & Low & High & Fruits and vegetables & Bonaccio et al., 2017 \\
\hline & Carotenoids & Low & High & Fruits and vegetables & $\begin{array}{l}\text { Marhuenda-Munoz } \\
\text { et al., } 2019\end{array}$ \\
\hline & Phytosterols & Low & High & Fruits and vegetables & Escurriol et al., 2009 \\
\hline & Phytoestrogens & Low & High & Fruits and vegetables & Ogce et al., 2008 \\
\hline & Glucosinolates & Low & High & Fruits and vegetables & Del Bo et al., 2019 \\
\hline
\end{tabular}

Tokura et al., 2005; Nakano et al., 2008; Chung and Champagne, 2009a; Shim et al., 2009b; Zuercher et al., 2010; Kamei et al., 2017). Promisingly, in vitro and in vivo studies, including in humans, have suggested that polyphenols can act on the sensitization as well as on the re-exposure immune mechanisms to allergens (Singh et al., 2011). For instance, polyphenols can impair the presentation of food antigens by APCs, namely dendritic cells, to allergen-specific $\mathrm{T}$ cells, promote a decrease in intestinal mast cell proteases release (Zuercher et al., 2010), induce the reduction of local intestinal mRNA expression of several Th2 associated and pro-inflammatory genes (MacDonald and Monteleone, 2005; Zhu, 2017) and impact IgE production by B cells (Singh et al., 2011).

Despite growing research are being conducted regarding the role of polyphenols in food allergies by direct antiallergenic mechanisms or indirectly through modulating gut microbiota some concerns must be considered. Most in vitro studies are performed by using isolated polyphenols or extracts but only a large minority of these compounds reach the colon intact. Under this context, metabolomics approaches must be conducted to understand the immunomodulatory action of polyphenols metabolites. Likewise, the high structural variability as well as 
the already mentioned diversity in extraction methods claim for further studies correlating the structure/activity relationships and effects on extraction methods in polyphenols functionality.

\section{Polyphenol/Protein Interactions as a Mechanism to Modulate Food Allergy}

Besides their anti-inflammatory and anti-allergic properties, polyphenols possess a significant binding affinity for proteins, which can lead to the formation of soluble and insoluble proteinphenolic complexes (Perez-Gregorio et al., 2014; Dias et al., 2015, 2016; Fernandes et al., 2016; Brandão et al., 2017). Antigens that elicit FA reactions are usually proteins. Indeed, recent studies revealed the interaction between polyphenols and food allergens (Shen et al., 2014; Wang et al., 2014; Vesic et al., 2015; AlHanish et al., 2016) which could induce conformational changes in the allergen (Wang et al., 2014; Vesic et al., 2015). However, whereas the polyphenol binding capacity was already proved in different food allergens, the influence in each step that leads to FA development have not been studied yet. Furthermore, polyphenol-protein interactions have already described as have potentially significant biochemical implications in the digestion (Soares et al., 2015) nevertheless is still a gap in the polyphenols effect in allergen digestion.

Overall, it was already described that polyphenols may bind to food antigens and conformational changes are consequently induced. Protein digestibility, conformation, and aggregation might be important for biological activities of dietary proteins that elicit hypersensitivity reactions in humans. IgE-binding capacity and activation of effectors cells, uptake by antigenpresenting cells and sensitizing potential of food allergens in allergy are the biological factors key for the disease onset. However, there is still a gap in the knowledge as how allergenpolyphenol complexes could influence the immune response. Little studies tentatively proved the inhibition of the IgE-binding activity through allergen-polyphenol interaction (Chung and Champagne, 2009a; Gray et al., 2015). It was also studied that some insoluble complexes could block the allergen availability (Chung and Champagne, 2009a). However, these studies should be interpreted with caution as were based the native unmodified forms of allergen that might suffer previous digestive and metabolic steps (Cardona et al., 2013). Several mechanisms prompted by polyphenols seem to be effective in allergic sensitization, a) their ability to bind with allergenic proteins ( $\mathrm{Li}$ and Mattison, 2018; Bansode et al., 2019; Plundrich et al., 2019) or to IgE (Bansode et al., 2019; Yousef et al., 2020) b) the protective effect as anti-inflammatory and antioxidant compounds (Zhou et al., 2020) and/or c) the ability to modulate cell functions either dampening MHC-II and co-stimulatory molecule expression or inhibiting cytokine production (Zuercher et al., 2010), or increasing their expression on Treg cells (Kim et al., 2007), thus hampering the antigen presentation process. Polyphenols could also influence FA during elicitation. Indeed, polyphenols inhibited the activation, proliferation and function of Th-2 cells during re-exposure to allergen in sensitized individuals (Singh et al., 2011). The polyphenol ingestion also attenuates the allergenic re-exposure by inhibition of adhesion and migration of peripheral B-cells, IgA-attenuating (Camps-Bossacoma et al.,

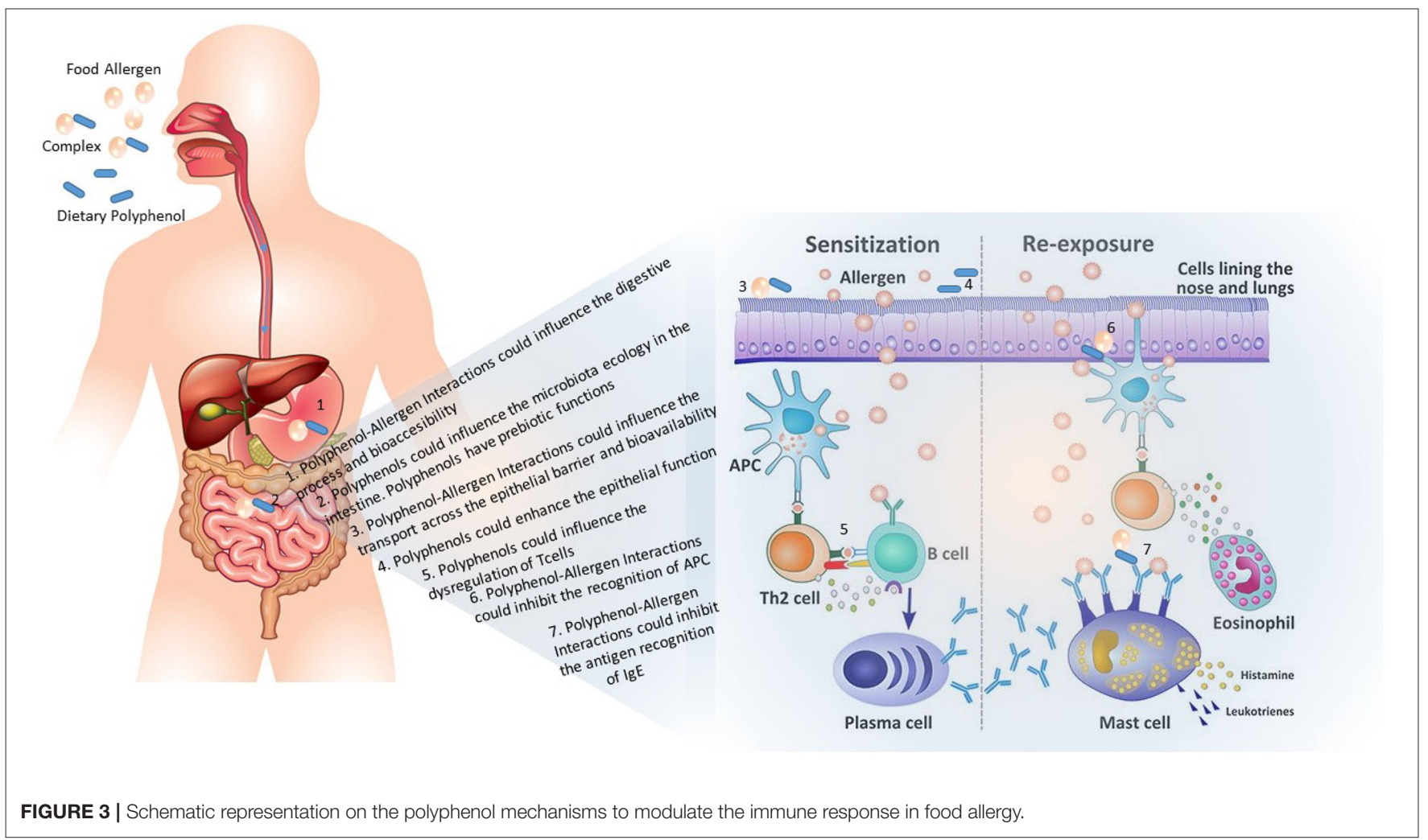


2019), suppression of IgE and IgG1 levels and abrogation of Th-2 cytokines (Singh et al., 2011; Mine et al., 2020). Growing scientific research also related the consumption of dietary polyphenols with the composition of gut microbiota and function (Sun et al., 2018). Indeed, the ingestion of polyphenols have been related with the growth of specific gut microbiota that have been shown to modulate Treg production (Turroni et al., 2020).

Altogether, although the data collected during the last years could help to understand the polyphenol's potential mechanisms of action (summarized in Figure 3), the metabolism, interactions with host and/or with other dietary factors as well as intrinsic variations within individuals remain largely unknown. According to the diversity of mechanisms proposed, the biological effect of polyphenols is likely the interplay between all of them. Furthermore, the digestion, metabolism and bioavailability of polyphenol, allergens and allergen-polyphenol complexes have to be well-understood when studying their immunomodulatory effects. Scientific knowledge must be improved to establish the basis for nutritional recommendations which could help preventing or minimize the prevalence and symptoms of FA.

\section{CONCLUSIONS}

Polyphenols are bioactive compound usually found in agri-food wastes with widely proven potential to be incorporated in the formulation of functional foods designed to prevent the increase of non-communicable diseases. Healthy constraints must go hand in hand with climate constraints claiming for the use of bioactive compounds from wastes in a circular economy approach. The epidemic increase in immune reactions to food allergens claim for stablishing nutritional recommendations able to control this rise. Based in aforesaid evidences, there is an unmet need to evaluate new therapeutic modalities in a nutritional approach (functional foods or supplements) that may decrease the risk of food-induced anaphylaxis and improve patients' quality of life. However, there is still a lack in the real intake of polyphenols through diet given the lack of standardized methods to characterize them from both, food components and agri-food wastes. Some missing links need to be addressed to actively modulate the immune system through diet and food systems via polyphenols. Active components and metabolites within different polyphenols extracts must be identified considering the inter-personal variability. Besides, complex in vitro systems must be designed for a better understanding of mechanistic studies and the cellular impact of polyphenols depending on anatomical locations (gut vs. blood) or intervention window (prevention vs. treatment). Furthermore, safe concerns must be explored in terms of maximum recommended daily intake, presence of toxic substances from extraction methods and overall cytotoxic activities. Whether used as therapy or as dietary interventions, their long-term safety

\section{REFERENCES}

Ajila, C. M., Brar, S. K., Verma, M., Tyagi, R. D., Godbout, S., and Valéro, J. R. (2011). Extraction and analysis of polyphenols: recent trends. Criti. Rev. Biotechnol. 31, 227-249. doi: 10.3109/07388551.2010.513677 profile needs to be addressed in different age groups. This review summarizes the pros and cons of the existent analytical methods to properly characterize polyphenols as the basis for the study in the use of polyphenols as modulators of immune reactions to food. Furthermore, the polyphenols bioavailability and metabolism, the polyphenols effect in gut microbiota and the ability to bind to proteins and cell receptors have to be studied in order to recommend the consumption of polyphenols to prevent the rise of food allergy.

\section{AUTHOR CONTRIBUTIONS}

TF and RP-G conceived and planned the overall review. RP-G devised the project, the main conceptual ideas, and proof outline. TF and CB took the lead and supervise in writing the manuscript, in consultation with all authors. TF carried out the documentation and writing in the analysis of polyphenols from agri-food wastes. CB planned and wrote the scientific section of the review related with the nature and food allergy related to immunology area. $\mathrm{RD}$ aided in interpreting the documents consulted and worked on the manuscript. NM and VF developed the theoretical formalism and were in charge of overall direction and planning. All authors provided critical feedback and helped shape the research, analysis, and manuscript.

\section{FUNDING}

This work was financial supported by Portuguese funds through FCT-Fundação para a Ciência e a Tecnologia-in the framework of the POCI-01-0247-FEDER-046080-PTDC/SAUNUT/30448/2017.

\section{ACKNOWLEDGMENTS}

This work was supported by the Associated Laboratory for Sustainable Chemistry, Clean Processes and Technologies through the national funds from UIDB/50006/2020. RP-G would like to thank FCT for her contract (SFRH/BPD/85293/2012). This work was financed by FEDER (Fundo Europeu de Desenvolvimento Regional) funds through the COMPETE 2020-Operacional Programme for Competitiveness and Internationalization (POCI), and by Portuguese funds through FCT-Fundação para a Ciência e a Tecnologia-in the framework of the POCI-01-0247-FEDER-046080-PTDC/SAUNUT/30448/2017 and PTDC/OCE-ETA/32287/2017 projects. This research was also supported by AgriFood XXI I\&D\&I project (NORTE-01-0145-FEDER-000041) co-financed by European Regional Development Fund (ERDF), through the NORTE 2020 (Programa Operacional Regional do Norte 2014/2020).

Al-Hanish, A., Stanic-Vucinic, D., Mihailovic, J., Prodic, I., Minic, S., Stojadinovic, M., et al. (2016). Noncovalent interactions of bovine $\alpha$-lactalbumin with green tea polyphenol, epigalocatechin3-gallate. Food Hydrocoll. 61, 241-250. doi: 10.1016/j.foodhyd.2016. 05.012 
Allen, K. J., Koplin, J. J., Ponsonby, A.-L., Gurrin, L. C., Wake, M., Vuillermin, P., et al. (2013). Vitamin D insufficiency is associated with challenge-proven food allergy in infants. J. Allergy Clin. Immunol. 131, 1109-1116.e1106. doi: 10.1016/j.jaci.2013. 01.017

Altinok, E., Palabiyik, I., Gunes, R., Toker, O. S., Konar, N., and Kurultay, S. (2020). Valorisation of grape by-products as a bulking agent in soft candies: effect of particle size. Lwt 118:108776. doi: 10.1016/j.lwt.2019.10 8776

Altomare, R., Cacciabaudo, F., Damiano, G., Palumbo, V. D., Gioviale, M. C., Bellavia, M., et al. (2013). The mediterranean diet: a history of health. Iran. J. Public Health 42:449.

Anvari, S., Miller, J., Yeh, C. Y., and Davis, C. M. (2019). IgE-mediated food allergy. Clin. Rev. Allergy Immunol. 57, 244-260. doi: 10.1007/s12016-018-8710-3

Arroyo Hornero, R., Hamad, I., Côrte-Real, B., and Kleinewietfeld, M. (2020). The impact of dietary components on regulatory $\mathrm{T}$ cells and disease. Front. Immunol. 11:253. doi: 10.3389/fimmu.2020.00253

Atta ur, R., and Iqbal Choudhary, M. (Eds.). (2015). Applications of NMR Spectroscopy. Sharjah: Bentham Science Publishers.

Ballesteros-Vivas, D., Ortega-Barbosa, J. P., Sánchez-Camargo, A. P., Rodríguez-Varela, L. I., and Parada-Alfonso, F. (2020). Pressurized liquid extraction of bioactives. Module Food Sci. 240, 105-113. doi: 10.1016/B978-0-08-100596-5.22817-5

Bansode, R. R., Randolph, P. D., Plundrich, N. J., Lila, M. A., and Williams, L. L. (2019). Peanut protein-polyphenol aggregate complexation suppresses allergic sensitization to peanut by reducing peanut-specific IgE in $\mathrm{C} 3 \mathrm{H} / \mathrm{HeJ}$ mice. Food Chem. 299:125025. doi: 10.1016/j.foodchem.2019.125025

Barba, F. J., Putnik, P., Bursać Kovačevi,ć, D., Poojary, M. M., Roohinejad, S., Lorenzo, J. M., et al. (2017). Impact of conventional and non-conventional processing on prickly pear (Opuntia spp.) and their derived products: From preservation of beverages to valorization of by-products. Trends Food Sci. Technol. 67, 260-270. doi: 10.1016/j.tifs.2017.07.012

Belščak-Cvitanović, A., Durgo, K., Hudek, A., Bačun-DruŽina, V., and Komes, D. (2018). Overview of polyphenols and their properties. Polyphenols 2018, 3-44. doi: 10.1016/B978-0-12-813572-3.00001-4

Belwal, T., Ezzat, S. M., Rastrelli, L., Bhatt, I. D., Daglia, M., Baldi, A., et al. (2018). A critical analysis of extraction techniques used for botanicals: Trends, priorities, industrial uses and optimization strategies. TrAC Trends Analyt. Chem. 100, 82-102. doi: 10.1016/j.trac.2017.12.018

Berardini, N., Knödler, M., Schieber, A., and Carle, R. (2005). Utilization of mango peels as a source of pectin and polyphenolics. Innov. Food Sci. Emerg. Technol. 6, 442-452. doi: 10.1016/j.ifset.2005.06.004

Bird, J. A., Lack, G., and Perry, T. T. (2015). Clinical management of food allergy. J Allergy Clin Immunol. Pract. 3, 1-11. doi: 10.1016/j.jaip.2014.06.008

Birt, D. F., and Jeffery, E. (2013). Nutrient information of flavonoids. Adv. Nutr. 1, 576-577. doi: 10.3945/an.113.004465

Bonaccio, M., Pounis, G., Cerletti, C., Donati, M. B., Iacoviello, L., and de Gaetano, G. (2017). Mediterranean diet, dietary polyphenols and low grade inflammation: results from the MOLI-SANI study. Br. J. Clin. Pharmacol. 83, 107-113. doi: 10.1111/bcp.12924

Bosiljkov, T., Dujmić, F., Bubalo, M. C., Hribar, J., Vidrih, R., Brnčić, M., et al. (2017). Natural deep eutectic solvents and ultrasound-assisted extraction: Green approaches for extraction of wine lees anthocyanins. Food Bioprod. Process. 102, 195-203. doi: 10.1016/j.fbp.2016.12.005

Bouasla, I., Hamel, T., Barour, C., Bouasla, A., Hachouf, M., Bouguerra, O. M., et al. (2021). Evaluation of solvent influence on phytochemical content and antioxidant activities of two Algerian endemic taxa: Stachys marrubiifolia Viv. and Lamium flexuosum Ten. (Lamiaceae). Eur. J. Integrat. Med. 42:101267. doi: 10.1016/j.eujim.2020.101267

Boussetta, N., Turk, M., De Taeye, C., Larondelle, Y., Lanoisellé, J. L., and Vorobiev, E. (2013). Effect of high voltage electrical discharges, heating and ethanol concentration on the extraction of total polyphenols and lignans from flaxseed cake. Ind. Crops Prod. 49, 690-696. doi: 10.1016/j.indcrop.2013.06.004

Brandão, E., Santos Silva, M., García-Estévez, I., Mateus, N., de Freitas, V., and Soares, S. (2017). Molecular study of mucin-procyanidin interaction by fluorescence quenching and Saturation Transfer Difference (STD)-NMR. Food Chem. 228, 427-434. doi: 10.1016/j.foodchem.2017.02.027
Briones-Labarca, V., Plaza-Morales, M., Giovagnoli-Vicuña, C., and Jamett, F. (2015). High hydrostatic pressure and ultrasound extractions of antioxidant compounds, sulforaphane and fatty acids from Chilean papaya (Vasconcellea pubescens) seeds: effects of extraction conditions and methods. LWT - Food Sci. Technol. 60, 525-534. doi: 10.1016/j.lwt.2014. 07.057

Bubalo, M. C., Curko, N., Tomašević, M., Ganić, K. K., and Redovniković, I. R. (2016). Green extraction of grape skin phenolics by using deep eutectic solvents. Food Chem. 200, 159-166. doi: 10.1016/j.foodchem.2016.01.040

Calderón-Oliver, M., and Ponce-Alquicira, E. (2018). Fruits: A Source of Polyphenols and Health Benefits. Cambridge, MA: Academic Press. doi: 10.1016/B978-0-12-811518-3.00007-7

Camps-Bossacoma, M., Massot-Cladera, M., Pérez-Cano, F. J., and Castell, M. (2019). Influence of a cocoa-enriched diet on the intestinal immune system and microbiota," in Dietary Interventions in Gastrointestinal Diseases, eds. R. R. Watson and V. R. Preedy (Cambridge, MA: Academic Press), 213-225. doi: 10.1016/B978-0-12-814468-8.00018-1

Carabias-Martínez, R., Rodríguez-Gonzalo, E., Revilla-Ruiz, P., and Hernández-Méndez, J. (2005). Pressurized liquid extraction in the analysis of food and biological samples. J. Chromatography A 1089, 1-17. doi: 10.1016/j.chroma.2005.06.072

Cardona, F., Andrés-Lacueva, C., Tulipani, S., Tinahones, F. J., and QueipoOrtuño, M. I. (2013). Benefits of polyphenols on gut microbiota and implications in human health. J. Nutr. Biochem. 24, 1415-1422. doi: 10.1016/j.jnutbio.2013.05.001

Casas, L., Mantell, C., Rodríguez, M., Ossa, E. J. M.,dl Roldán, A., Ory, I. D., et al. (2010). Extraction of resveratrol from the pomace of Palomino fino grapes by supercritical carbon dioxide. J. Food Eng. 96, 304-308. doi: 10.1016/j.jfoodeng.2009.08.002

Chang, C. J., Chiu, K. L., Chen, Y. L., and Chang, C. Y. (2000). Separation of catechins from green tea using carbon dioxide extraction. Food Chem. 68, 109-113. doi: 10.1016/S0308-8146(99)00176-4

Chemat, F., Abert-vian, M., Fabiano-tixier, A. S., Strube, J., Uhlenbrock, L., Gunjevic, V., et al. (2019). Trends in analytical chemistry green extraction of natural products. Origins Curr Status Future Challenges 118, 248-263. doi: 10.1016/j.trac.2019.05.037

Chistiakov, D. A., Bobryshev, Y. V., Kozarov, E., Sobenin, I. A., and Orekhov, A. N. (2015). Intestinal mucosal tolerance and impact of gut microbiota to mucosal tolerance. Front. Microbiol. 5:781. doi: 10.3389/fmicb.2014.00781

Chung, S., and Champagne, E. T. (2009b). Ferulic acid enhances IgE binding to peanut allergens in western blots. J. Allergy Clin. Immunol. 123:S192. doi: $10.1016 /$ j.jaci.2008.12.727

Chung, S.-Y., and Champagne, E. T. (2009a). Reducing the allergenic capacity of peanut extracts and liquid peanut butter by phenolic compounds. Food Chem. 115, 1345-1349. doi: 10.1016/j.foodchem.2009.01.052

Connors, L., O'Keefe, A., Rosenfield, L., and Kim, H. (2018). Non-IgEmediated food hypersensitivity. Allergy Asthma Clin. Immunol. 14:56. doi: 10.1186/s13223-018-0285-2

Contreras, M. M., Lama-Muñoz, A., Espínola, F., Moya, M., Romero, I., and Castro, E. (2020). Valorization of olive mill leaves through ultrasound-assisted extraction. Food Chem. 314, 126218-126218. doi: 10.1016/j.foodchem.2020.126218

Cory, H., Passarelli, S., Szeto, J., Tamez, M., and Mattei, J. (2018). The role of polyphenols in human health and food systems: a mini-review. Front. Nutr. 5:87. doi: $10.3389 /$ fnut.2018.00087

de Araújo, F. F., de Paulo Farias, D., Neri-Numa, I. A., and Pastore, G. M. (2020). Polyphenols and their applications: an approach in food chemistry and innovation potential. Food Chem. 338, 127535-127535. doi: 10.1016/j.foodchem.2020.127535

De Martinis, M., Sirufo, M. M., Viscido, A., and Ginaldi, L. (2019). Food allergies and ageing. Int. J. Mol. Sci. 20:580. doi: 10.3390/ijms20225580

De Pergola, G., and D'Alessandro, A. (2018). Influence of Mediterranean diet on blood pressure. Nutrients 10:1700. doi: 10.3390/nu10111700

Dedousi, M., Mamoudaki, V., Grigorakis, S., and Makris, D. P. (2017). Ultrasoundassisted extraction of polyphenolic antioxidants from olive (Olea europaea) leaves using a novel glycerol/sodium-potassium tartrate low-transition temperature mixture. Environments 4:31. doi: 10.3390/environments4020031 
Del Bo, C., Marino, M., Martini, D., Tucci, M., Ciappellano, S., Riso, P., et al. (2019). Overview of human intervention studies evaluating the impact of the mediterranean diet on markers of DNA damage. Nutrients 11:391. doi: 10.3390/nu11020391

Del Rio, D., Costa, L. G., Lean, M. E. J., and Crozier, A. (2010). Polyphenols and health: What compounds are involved? Nutr. Metab. Cardiovasc. Dis. 20, 1-6. doi: 10.1016/j.numecd.2009.05.015

Del Rio, D., Rodriguez-Mateos, A., Spencer, J. P. E., Tognolini, M., Borges, G., and Crozier, A. (2013). Dietary (poly)phenolics in human health: structures, bioavailability, and evidence of protective effects against chronic diseases. Antioxid. Redox Signal. 18, 1818-1892. doi: 10.1089/ars.2012.4581

Dias, R., Oliveira, H., Fernandes, I., Simal-Gandara, J., and Perez-Gregorio, R. (2020). Recent advances in extracting phenolic compounds from food and their use in disease prevention and as cosmetics. Crit. Rev. Food Sci. Nutr. 61, 1130-1151. doi: 10.1080/10408398.2020.1754162

Dias, R., Perez-Gregorio, M. R., Mateus, N., and De Freitas, V. (2016). Interaction study between wheat-derived peptides and procyanidin B3 by mass spectrometry. Food Chem. 194, 1304-1312. doi: 10.1016/j.foodchem.2015.08.108

Dias, R., Perez-Gregorio, R., Mateus, N., and De Freitas, V. (2015). The interaction between tannins and gliadin derived peptides in a celiac disease perspective. RSC Adv. 5, 32151-32158. doi: 10.1039/C5RA02968F

Domínguez-Rodríguez, G., Marina, M. L., and Plaza, M. (2017). Strategies for the extraction and analysis of non-extractable polyphenols from plants. J. Chromatograp. A 1514, 1-15. doi: 10.1016/j.chroma.2017.07.066

Durazzo, A., Lucarini, M., Souto, E. B., Cicala, C., Caiazzo, E., Izzo, A. A., et al. (2019). Polyphenols: a concise overview on the chemistry, occurrence, and human health. Phytother. Res. 33, 2221-2243. doi: 10.1002/ptr.6419

Dzah, C. S., Duan, Y., Zhang, H., Serwah Boateng, N. A., and Ma, H. (2020). Latest developments in polyphenol recovery and purification from plant by-products: A review. Trends Food Sci. Technol. 99, 375-388. doi: 10.1016/j.tifs.2020.03.003

El Gharras, H. (2009). Polyphenols: Food sources, properties and applications - a review. Int. J. Food Sci. Technol. 44, 2512-2518. doi: 10.1111/j.1365-2621.2009.02077.x

Escurriol, V., Cofán, M., Serra, M., Bull,ó, M., Basora, J., Salas-Salvad,ó, J., et al. (2009). Serum sterol responses to increasing plant sterol intake from natural foods in the Mediterranean diet. Eur. J. Nutr. 48, 373-382. doi: 10.1007/s00394-009-0024-Z

Esparza, I., Jim, N., Bimbela, F., Ancín-azpilicueta, C., and Gandía, L. M. (2020). Fruit and vegetable waste management: Conventional and emerging approaches. J. Environ. Manage. 265:110510. doi: 10.1016/j.jenvman.2020.110510

Esposito, T., Silva, N. H. C. S., Almeida, A., Silvestre, A. J. D., Piccinelli, A., Patrizia, R., et al. (2020). Industrial crops \& products valorisation of chestnut spiny burs and roasted hazelnut skins extracts as bioactive additives for packaging films. Indust. Crops Prod. 151:112491. doi: 10.1016/j.indcrop.2020.112491

Fernandes, I., Pérez-Gregorio, R., Soares, S., Mateus, N., and De Freitas, V. (2016). "Wine," in Fermented Foods in Health and Disease Prevention, eds J. Frias, C. Martinez-Villaluenga, and E. Peñas (Amsterdam: Elsevier Inc.), 593-621. doi: 10.1016/B978-0-12-802309-9.00026-1

Fernandes, I., Pérez-Gregorio, R., Soares, S., Mateus, N., and de Freitas, V. (2017). Wine flavonoids in health and disease prevention. Molecules 22:292. doi: 10.3390/molecules22020292

Garcia-herrero, I., Margallo, M., Laso, J., Batlle-bayer, L., Bala, A., and Fullana-ipalmer, P. (2019). Nutritional data management of food losses and waste under a life cycle approach: case study of the Spanish agri-food system. J. Food Comp. Analy. 82:103223. doi: 10.1016/j.jfca.2019.05.006

Giannuzzo, A. N., Boggetti, H. J., Nazareno, M. A., and Mishima, H. T. (2003). Supercritical fluid extraction of naringin from the peel of Citrus paradisi. Phytochem. Anal. 14, 221-223. doi: 10.1002/pca.706

Gómez-Donoso, C., Martínez-González, M. Á., Perez-Cornago, A., Sayón-Orea, C., Martínez, J. A., and Bes-Rastrollo, M. (2021). Association between the nutrient profile system underpinning the Nutri-Score front-of-pack nutrition label and mortality in the SUN project: A prospective cohort study. Clin. Nutr. 40, 1085-1094. doi: 10.1016/j.clnu.2020.07.008

Gómez-mejía, E., Roriz, C. L., Heleno, S. A., Dias, M. I., Pinela, J., Rosalesconrado, N., et al. (2020). Valorisation of black mulberry and grape seeds: chemical characterization and bioactive potential. Food Chem. 337:127998 doi: 10.1016/j.foodchem.2020.127998

Gowd, V., Karim, N., Shishir, M. R. I., Xie, L., and Chen, W. (2019). Dietary polyphenols to combat the metabolic diseases via altering gut microbiota. Trends Food Sci. Technol. 93, 81-93. doi: 10.1016/j.tifs.2019.09.005

Gray, C. L., Levin, M. E., and du Toit, G. (2015). Ethnic differences in peanut allergy patterns in South African children with atopic dermatitis. Pediatr. Allergy Immunol. 26, 721-730. doi: 10.1111/pai.12459

Gruber, P., Vieths, S., Wangorsch, A., Nerkamp, J., and Hofmann, T. (2004). Maillard reaction and enzymatic browning affect the allergenicity of Pru av 1, the major allergen from cherry (Prunus avium). J. Agric. Food Chem. 52, 4002-4007. doi: 10.1021/jf035458+

Gullón, P., Gullón, B., Roman,í, A., Rocchetti, G., and Lorenzo, J. M. (2020). Smart advanced solvents for bioactive compounds recovery from agri-food by-products: a review. Trends Food Sci. Technol. 101, 182-197. doi: 10.1016/j.tifs.2020.05.007

Herrero, M., Mendiola, J. A., Cifuentes, A., and Ibáñez, E. (2010). Supercritical fluid extraction: recent advances and applications. J. Chromatograp. A 1217, 2495-2511. doi: 10.1016/j.chroma.2009.12.019

Hirsch, A. G., Pollak, J., Glass, T. A., Poulsen, M. N., Bailey-Davis, L., Mowery, J., et al. (2017). Early-life antibiotic use and subsequent diagnosis of food allergy and allergic diseases. Clin. Exp. Allergy 47, 236-244. doi: 10.1111/cea. 12807

Hong, S. W., Kim, K. S., and Surh, C. D. (2017). Beyond hygiene: commensal microbiota and allergic diseases. Immune. Netw. 17, 48-59. doi: 10.4110/in.2017.17.1.48

Ignat, I., Volf, I., and Popa, V. I. (2011). A critical review of methods for characterisation of polyphenolic compounds in fruits and vegetables. Food Chem. 126, 1821-1835. doi: 10.1016/j.foodchem.2010.12.026

Jonsson, K., Green, M., Barman, M., Sjöberg, A., Brekke, H. K., Wold, A. E., et al. (2016). Diet in 1-year-old farm and control children and allergy development: Results from the FARMFLORA birth cohort. Food Nutr. Res. 60:32721. doi: 10.3402/fnr.v60.32721

Kamei, R., Fujimura, T., Matsuda, M., Kakihara, K., Hirakawa, N., Baba, K., et al. (2017). A flavanone derivative from the Asian medicinal herb (Perilla frutescens) potently suppresses IgE-mediated immediate hypersensitivity reactions. Biochem. Biophys. Res. Commun. 483, 674-679. doi: 10.1016/j.bbrc.2016.12.083

Kamer, B., Wasowicz, W., Pyziak, K., Kamer-Bartosinska, A., Gromadzinska, J., and Pasowska, R. (2012). Role of selenium and zinc in the pathogenesis of food allergy in infants and young children. Arch. Med. Sci. 8, 1083-1088. doi: 10.5114/aoms.2012.32420

Kanda, T., Akiyama, H., Yanagida, A., Tanabe, M., Goda, Y., Toyoda, M., et al. (1998). Inhibitory effects of apple polyphenol on induced histamine release from RBL-2H3 cells and rat mast cells. Biosci. Biotechnol. Biochem. 62, 1284-1289. doi: 10.1271/bbb.62.1284

Kelebek, H., Selli, S., Kadiroglu, P., Kola, O., Kesen, S., Uçar, B., and Çetiner, B. (2017). Bioactive compounds and antioxidant potential in tomato pastes as affected by hot and cold break process. Food Chem. 220, 31-41. doi: 10.1016/j.foodchem.2016.09.190

Kelly, N. P., Kelly, A. L., and O’Mahony, J. A. (2019). Strategies for enrichment and purification of polyphenols from fruit-based materials. Trends Food Sci. Technol. 83, 248-258. doi: 10.1016/j.tifs.2018.11.010

Khoddami, A., Wilkes, M. A., and Roberts, T. H. (2013). Techniques for analysis of plant phenolic compounds. Molecules 18, 2328-2375. doi: 10.3390/molecules 18022328

Kim, J. Y., Kina, T., Iwanaga, Y., Noguchi, H., Matsumura, K., and Hyon, S. H. (2007). Tea polyphenol inhibits allostimulation in mixed lymphocyte culture. Cell Transplant. 16, 75-83. doi: 10.3727/000000007783464515

Ko, M.-J., Cheigh, C.-I., Cho, S.-W., and Chung, M.-S. (2011). Subcritical water extraction of flavonol quercetin from onion skin. J. Food Eng. 102, 327-333. doi: 10.1016/j.jfoodeng.2010.09.008

Kobernick, A. K., and Burks, A. W. (2016). Active treatment for food allergy. Scand. J. Immunol. 65, 388-395. doi: 10.1016/j.alit.2016.08.002

Kontogianni, V. G. (2014). Novel techniques towards the identification of different classes of polyphenols. Polyphenols Plants 2014, 159-185. doi: 10.1016/B978-0-12-397934-6.00008-5 
Kumar, B. R. (2017). Application of HPLC and ESI-MS techniques in the analysis of phenolic acids and flavonoids from green leafy vegetables (GLVs). J. Pharm. Analy. 7, 349-364. doi: 10.1016/j.jpha.2017.06.005

Kumar, K. (2020). Nutraceutical potential and utilization aspects of food industry by-products and wastes. Food Indus. Wastes 2020, 89-111. doi: 10.1016/B978-0-12-817121-9.00005-X

Li, Y., and Mattison, C. P. (2018). Polyphenol-rich pomegranate juice reduces IgE binding to cashew nut allergens. J. Sci. Food Agric. 98, 1632-1638. doi: $10.1002 /$ jsfa. 8639

Libro, R., Giacoppo, S., Rajan, T. S., Bramanti, P., and Mazzon, E. (2016). Natural phytochemicals in the treatment and prevention of dementia: an overview. Molecules 21:518. doi: 10.3390/molecules 21040518

Lieberman, P., Nicklas, R. A., Randolph, C., Oppenheimer, J., Bernstein, D., Bernstein, J., et al. (2015). Anaphylaxis-a practice parameter update 2015. Ann. Allergy Asthma Immunol. 115, 341-384. doi: 10.1016/j.anai.2015.07.019

López-fernández, O., Domínguez, R., Pateiro, M., Munekata, P. E. S., Rocchetti, G., and Lorenzo, J. M. (2020). Determination of polyphenols using liquid chromatography-tandem mass spectrometry technique (LC-MS/MS): a review. Antioxidants 9, 1-27. doi: 10.3390/antiox9060479

Louis, C., Akanbi, T. O., Mason, B., Udenigwe, C. C., and Aryee, A. N. A. (2019). Influence of conventional and recent extraction technologies on physicochemical properties of bioactive macromolecules from natural sources: a review. Food Res. Int. 116, 827-839. doi: 10.1016/j.foodres.2018.09.018

Lucci, P., Saurina, J., and Núñez, O. (2017). Trends in LC-MS and LC-HRMS analysis and characterization of polyphenols in food. TrAC - Trends Analy. Chem. 88, 1-24. doi: 10.1016/j.trac.2016.12.006

Ma, Y. Q., Chen, J. C., Liu, D. H., and Ye, X. Q. (2009). Simultaneous extraction of phenolic compounds of citrus peel extracts: effect of ultrasound. Ultrason. Sonochem. 16, 57-62. doi: 10.1016/j.ultsonch.2008.04.012

MacDonald, T. T., and Monteleone, G. (2005). Immunity, inflammation, and allergy in the gut. Science 307, 1920-1925. doi: 10.1126/science.1106442

Magaton, S., Miranda, F. M. D., and Dias, F. D. S. (2020). Greener ultrasoundassisted extraction of bioactive phenolic compounds in Croton heliotropiifolius Kunth leaves. Microchem. J. 159:105525. doi: 10.1016/j.microc.2020.105525

Maier, T., Schieber, A., Kammerer, D. R., and Carle, R. (2009). Residues of grape (Vitis vinifera L.) seed oil production as a valuable source of phenolic antioxidants. Food Chem. 112, 551-559. doi: 10.1016/j.foodchem.2008.06.005

Manach, C., Scalbert, A., Morand, C., Rémésy, C., and Jiménez, L. (2004). Polyphenols: Food sources and bioavailability. Am. J. Clin. Nutr. 79, 727-747. doi: $10.1093 /$ ajen/79.5.727

Marhuenda-Munoz, M., Hurtado-Barroso, S., Tresserra-Rimbau, A., and Lamuela-Raventos, R. M. (2019). A review of factors that affect carotenoid concentrations in human plasma: differences between Mediterranean and Northern diets. Eur. J. Clin. Nutr. 72, 18-25. doi: 10.1038/s41430-018-0305-9

Maroun, R. G., Rajha, H. N., El Darra, N., El Kantar, S., Chacar, S., Debs, E., et al. (2018). Emerging technologies for the extraction of polyphenols from natural sources. Polyphenols 2008, 265-293. doi: 10.1016/B978-0-12-813572-3.00008-7

Mathys, A., Chaudhary, A., and Gustafson, D. (2018). Multi-indicator sustainability assessment of global food systems. Nat. Commun. 9:848. doi: 10.1038/s41467-018-03308-7

Meregalli, M. M., Puton, B. M. S., Camera, F. D. M., Amaral, A. U., Zeni, J., Cansian, R. L., et al. (2020). Conventional and ultrasound-assisted methods for extraction of bioactive compounds from red araçá peel (Psidium cattleianum Sabine). Arab. J. Chem. 13, 5800-5809. doi: 10.1016/j.arabjc.2020.04.017

Mine, Y., Majumder, K., Jin, Y., and Zeng, Y. (2020). Chinese sweet tea (Rubus suavissimus) polyphefnols attenuate the allergic responses in a Balb/c mouse model of egg allergy. J. Funct. Foods 67:103827. doi: 10.1016/j.jff.2020.103827

Mirabella, N., Castellani, V., and Sala, S. (2014). Current options for the valorization of food manufacturing waste: a review. J. Clean. Product. 65, 28-41. doi: 10.1016/j.jclepro.2013.10.051

Mirmiran, P., Gaeini, Z., Bahadoran, Z., Ghasemi, A., Norouzirad, R., Tohidi, M., et al. (2021). Urinary sodium-to-potassium ratio: a simple and useful indicator of diet quality in population-based studies. Eur. J. Med. Res. 26:3. doi: 10.1186/s40001-020-00476-5

Mitselou, N., Hallberg, J., Stephansson, O., Almqvist, C., Melen, E., and Ludvigsson, J. F. (2018). Cesarean delivery, preterm birth, and risk of food allergy: Nationwide Swedish cohort study of more than 1 million children.
J. Allergy Clin. Immunol. 142, 1510-1514.e1512. doi: 10.1016/j.jaci.2018. 06.044

Mohrenschlager, M., and Ring, J. (2011). Food allergy: an increasing problem for the elderly. Gerontology 57, 33-36. doi: 10.1159/000316576

Monteil-Rivera, F., Huang, G. H., Paquet, L., Deschamps, S., Beaulieu, C., and Hawari, J. (2012). Microwave-assisted extraction of lignin from triticale straw: Optimization and microwave effects. Biores. Technol. 104, 775-782. doi: 10.1016/j.biortech.2011.11.079

Mourtzinos, I., and Goula, A. (2019). Polyphenols in agricultural byproducts and food waste. Polyphenols Plants 2019, 23-44. doi: 10.1016/B978-0-12-813768-0.00002-5

Mrduljaš, N., Krešić, G., and Bilušić, T. (2017). "Polyphenols: food sources and health benefits," in Functional Food-Improve Health Through Adequate Food, 23-41. doi: 10.5772/intechopen.68862

Muraro, A., Werfel, T., Hoffmann-Sommergruber, K., Roberts, G., Beyer, K., Bindslev-Jensen, C., et al. (2014). EAACI food allergy and anaphylaxis guidelines: diagnosis and management of food allergy. Allergy 69, 1008-1025. doi: $10.1111 /$ all.12429

Myles, I. A. (2014). Fast food fever: reviewing the impacts of the Western diet on immunity. Nutr. J. 13:61. doi: 10.1186/1475-2891-13-61

Naczk, M., and Shahidi, F. (2004). Extraction and analysis of phenolics in food. J. Chromatograp. A 1054, 95-111. doi: 10.1016/S0021-9673(04)01409-8

Naczk, M., and Shahidi, F. (2006). Phenolics in cereals, fruits and vegetables: Occurrence, extraction and analysis. J. Pharm. Biomed. Anal. 41, 1523-1542. doi: $10.1016 /$ j.jpba.2006.04.002

Nakano, N., Nishiyama, C., Tokura, T., Nagasako-Akazome, Y., Ohtake, Y., Okumura, K., et al. (2008). Procyanidin C1 from apple extracts inhibits FceRImediated mast cell activation. Int. Arch. Allergy Immunol. 147, 213-221. doi: 10.1159/000142044

Ogce, F., Ceber, E., Ekti, R., and Oran, N. T. (2008). Comparison of mediterranean, Western and Japanese diets and some recomçmendations. Asian Pac. J. Cancer Prev. 9, 351-356.

Ortega, R. (2006). Importance of functional foods in the Mediterranean diet. Public Health Nutr. 9, 1136-1140. doi: 10.1017/S1368980007668530

Pali-Schöll, I., Untersmayr, E., Klems, M., and Jensen-Jarolim, E. (2018). The effect of digestion and digestibility on allergenicity of food. Nutrients 10:1129. doi: 10.3390/nu10091129

Panel, N. I.-S. E., Boyce, J. A., Assa’ad, A., Burks, A. W., Jones, S. M., Sampson, H. A., et al. (2010). Guidelines for the diagnosis and management of food allergy in the United States: report of the NIAID-sponsored expert panel. J. Allergy Clin. Immunol. 126, S1-58. doi: 10.1016/j.jaci.2010.10.007

Panić, M., Gunjević, V., Cravotto, G., and Redovniković, I. R. (2019). Enabling technologies for the extraction of grape-pomace anthocyanins using natural deep eutectic solvents in up-to-half-litre batches extraction of grape-pomace anthocyanins using NADES. Food Chem. 300:125185. doi: $10.1016 /$ j.foodchem.2019.125185

Panja, P. (2018). Green extraction methods of food polyphenols from vegetable materials. Curr. Opin. Food Sci. 23, 173-182. doi: 10.1016/j.cofs.2017.11.012

Panzella, L., Moccia, F., Nasti, R., Marzorati, S., Verotta, L., and Napolitano, A. (2020). Bioactive phenolic compounds from agri-food wastes: an update on green and sustainable extraction methodologies. Front. Nutr. 7:60. doi: $10.3389 /$ fnut. 2020.00060

Papaioannou, E. H., Mitrouli, S. T., Patsios, S. I., Kazakli, M., and Karabelas, A. J. (2020). Valorization of pomegranate husk - integration of extraction with nano fi ltration for concentrated polyphenols recovery. J. Environ. Chem. Eng. 8:103951. doi: 10.1016/j.jece.2020.103951

Pascal, M., Perez-Gordo, M., Caballero, T., Escribese, M. M., Lopez Longo, M. N., Luengo, O., et al. (2018). Microbiome and allergic diseases. Front. Immunol. 9:1584. doi: 10.3389/fimmu.2018.01584

Perez-Gregorio, M. R., Mateus, N., and De Freitas, V. (2014). New procyanidin B3-human salivary protein complexes by mass spectrometry. Effect of salivary protein profile, tannin concentration, and time stability. J. Agricult. Food Chem. 62, 10038-10045. doi: 10.1021/jf5033284

Perez-Gregorio, R., and Simal-Gandara, J. (2017). A critical review of bioactive food components, and of their functional mechanisms, biological effects and health outcomes. Curr. Pharm. Des. 23, 2731-2741. doi: $10.2174 / 1381612823666170317122913$ 
Piccolella, S., Crescente, G., Candela, L., and Pacifico, S. (2019). Nutraceutical polyphenols: New analytical challenges and opportunities. J. Pharm. Biomed. Anal. 175, 112774-112774. doi: 10.1016/j.jpba.2019.07.022

Piccolella, S., Crescente, G., Nocera, P., Pacifico, F., Manti, L., and Pacifico, S. (2018). Ultrasound-assisted aqueous extraction, LC-MS/MS analysis and radiomodulating capability of autochthonous Italian sweet cherry fruits. Food Function 9, 1840-1849. doi: 10.1039/C7FO01977G

Pimentel-Moral, S., de la Luz Cádiz-Gurrea, M., Rodríguez-Pérez, C., and Segura-Carretero, A. (2020). "Recent advances in extraction technologies of phytochemicals applied for the revaluation of agri-food by-products," in Functional and Preservative Properties of Phytochemicals, 209-239. doi: 10.1016/B978-0-12-818593-3.00007-5

Pinela, J., Prieto, M. A., Filomena, M., Maria, A., Oliveira, M. B. P. P., Curran, T. P., et al. (2017). Valorisation of tomato wastes for development of nutrient-rich antioxidant ingredients: a sustainable approach towards the needs of the today. Society. 41, 160-171. doi: 10.1016/j.ifset.2017.02.004

Plundrich, N. J., Cook, B. T., Maleki, S. J., Fourches, D., and Lila, M. A. (2019). Binding of peanut allergen Ara h 2 with vaccinium fruit polyphenols. Food Chem. 284, 287-295. doi: 10.1016/j.foodchem.2019.01.081

Popa, D. S., and Rusu, M. E. (2017). "Isoflavones: vegetable sources, biological activity, and analytical methods for their assessment," in Superfood and Functional Food-The Development of Superfoods and Their Roles as Medicine 133-153. doi: 10.5772/66531

Prescott, S. L., Pawankar, R., Allen, K. J., Campbell, D. E., Sinn, J. K. H., Fiocchi, A., et al. (2013). A global survey of changing patterns of food allergy burden in children. World Allergy Organization J. 6:21. doi: 10.1186/1939-45 51-6-21

Prioult, G., and Nagler-Anderson, C. (2005). Mucosal immunity and allergic responses: lack of regulation and/or lack of microbial stimulation? Immunol. Rev. 206, 204-218. doi: 10.1111/j.0105-2896.2005.00277.x

Pyrzynska, K., and Sentkowska, A. (2019). Chromatographic Analysis of Polyphenols. Amsterdam: Elsevier Inc. doi: 10.1016/B978-0-12813768-0.00021-9

Rodriguez, R., Salvatori, D., Sette, P., and Fernandez, A. (2020). Integral valorization of fruit waste from wine and cider industries n Mazza. J. Clean. Product. 242:118486. doi: 10.1016/j.jclepro.2019.118486

Routray, W., and Orsat, V. (2019). Agricultural and Food Industry By-Products: Source of Bioactive Components for Functional Beverages. Amsterdam: Elsevier Inc. doi: 10.1016/B978-0-12-816842-4.00015-0

Russo, M., Bonaccorsi, I., Inferrera, V., Dugo, P., and Mondello, L. (2015). Underestimated sources of flavonoids, limonoids and dietary fiber: availability in orange's by-products. J. Funct. Foods 12, 150-157. doi: 10.1016/j.jff.2014.11.008

Saifullah, M., McCullum, R., McCluskey, A., and Vuong, Q. (2020). Comparison of conventional extraction technique with ultrasound assisted extraction on recovery of phenolic compounds from lemon scented tea tree (Leptospermum petersonii) leaves. Heliyon 6:e03666. doi: 10.1016/j.heliyon.2020. e03666

Santhakumar, A. B., Battino, M., and Alvarez-Suarez, J. M. (2018). Dietary polyphenols: Structures, bioavailability and protective effects against atherosclerosis. Food Chem. Toxicol. 113, 49-65. doi: 10.1016/j.fct.2018.01.022

Seo, N., Ito, T., Wang, N., Yao, X., Tokura, Y., Furukawa, F., et al. (2005). Antiallergic Psidium guajava extracts exert an antitumor effect by inhibition of $\mathrm{T}$ regulatory cells and resultant augmentation of Th1 cells. Anticancer Res. 25, 3763-3770.

Serino, A., and Salazar, G. (2019). Protective role of polyphenols against vascular inflammation, aging and cardiovascular disease. Nutrients 11:53. doi: 10.3390/nu11010053

Shen, F., Niu, F., Li, J., Su, Y., Liu, Y., and Yang, Y. (2014). Interactions between tea polyphenol and two kinds of typical egg white proteins-ovalbumin and lysozyme: Effect on the gastrointestinal digestion of both proteins in vitro. Food Res. Int. 59, 100-107. doi: 10.1016/j.foodres.2014.01.070

Shim, S.-Y., Quang-To, L., Lee, S.-H., and Kim, S.-K. (2009a). Ecklonia cava extract suppresses the high-affinity IgE receptor, FceRI expression. Food Chem. Toxicol. 47, 555-560. doi: 10.1016/j.fct.2008.12.012

Shim, S.-Y., Seo, Y.-K., and Park, J.-R. (2009b). Down-regulation of FceRI expression by houttuynia cordata thunb extract in human basophilic KU812F cells. J. Med. Food 12, 383-388. doi: 10.1089/jmf.2007.0684
Sicherer, S. H., and Sampson, H. A. (2009). Food allergy: recent advances in pathophysiology and treatment. Annu. Rev. Med. 60, 261-277. doi: 10.1146/annurev.med.60.042407.205711

Sicherer, S. H., and Sampson, H. A. (2010). Food allergy. J. Allergy Clin. Immunol. 125(Suppl. 2), S116-125. doi: 10.1016/j.jaci.2009.08.028

Sicherer, S. H., and Sampson, H. A. (2018). Food allergy: A review and update on epidemiology, pathogenesis, diagnosis, prevention, and management. J. Allergy Clin. Immunol. 141, 41-58. doi: 10.1016/j.jaci.2017.11.003

Singh, A., Holvoet, S., and Mercenier, A. (2011). Dietary polyphenols in the prevention and treatment of allergic diseases. Clin. Exp. Allergy 41, 1346-1359. doi: 10.1111/j.1365-2222.2011.03773.x

Singh, R. K., Chang, H. W., Yan, D., Lee, K. M., Ucmak, D., Wong, K., et al. (2017). Influence of diet on the gut microbiome and implications for human health. J. Transl. Med. 15:73. doi: 10.1186/s12967-017-1175-y

Soares, S., Brandão, E., Mateus, N., and De Freitas, V. (2015). Interaction between red wine procyanidins and salivary proteins: effect of stomach digestion on the resulting complexes. RSC Adv. 5, 12664-12670. doi: 10.1039/C4RA13403F

Stalikas, C. D. (2007). Extraction, separation, and detection methods for phenolic acids and flavonoids. J. Sep. Sci. 30, 3268-3295. doi: 10.1002/jssc.200700261

Sun, H., Chen, Y., Cheng, M., Zhang, X., Zheng, X., and Zhang, Z. (2018). The modulatory effect of polyphenols from green tea, oolong tea and black tea on human intestinal microbiota in vitro. J. Food Sci. Technol. 55, 399-407. doi: 10.1007/s13197-017-2951-7

Tan, J., McKenzie, C., Vuillermin, P. J., Goverse, G., Vinuesa, C. G., Mebius, R. E., et al. (2016). Dietary fiber and bacterial SCFA enhance oral tolerance and protect against food allergy through diverse cellular pathways. Cell Rep. 15, 2809-2824. doi: 10.1016/j.celrep.2016.05.047

Tang, M. L., and Mullins, R. J. (2017). Food allergy: is prevalence increasing? Intern. Med. J. 47, 256-261. doi: 10.1111/imj.13362

Tappenden, K. A., and Deutsch, A. S. (2007). The physiological relevance of the intestinal microbiota - contributions to human health. J. Am. College Nutr. 26, 679S-683S. doi: 10.1080/07315724.2007.10719647

Tokura, T., Nakano, N., Ito, T., Matsuda, H., Nagasako-Akazome, Y., Kanda, T., et al. (2005). Inhibitory effect of polyphenol-enriched apple extracts on mast cell degranulation in vitro targeting the binding between IgE and FceRI. Biosci. Biotechnol. Biochem. 69, 1974-1977. doi: 10.1271/bbb.69.1974

Tresserra-rimbau, A., Rimm, E. B., Medina-remón, A., Martínez-gonzález, M. A., López-sabater, M. C., Covas, M. I., et al. (2014). Polyphenol intake and mortality risk: a re-analysis of the PREDIMED trial. BMC Med. 12:77. doi: 10.1186/1741-7015-12-77

Turroni, F., Milani, C., Duranti, S., Lugli, G. A., Bernasconi, S., Margolles, A., et al. (2020). The infant gut microbiome as a microbial organ influencing host well-being. Ital. J. Pediatr. 46:16. doi: 10.1186/s13052-020-0781-0

van Nimwegen, F. A., Penders, J., Stobberingh, E. E., Postma, D. S., Koppelman, G. H., Kerkhof, M., et al. (2011). Mode and place of delivery, gastrointestinal microbiota, and their influence on asthma and atopy. J. Allergy Clin. Immunol. 128, 948-955.e941-943. doi: 10.1016/j.jaci.2011.07.027

Ventura, M. T., D’Amato, A., Giannini, M., Carretta, A., Tummolo, R. A., and Buquicchio, R. (2010). Incidence of allergic diseases in an elderly population. Immunopharmacol. Immunotoxicol. 32, 165-170. doi: 10.3109/08923970903213735

Vesic, J., Stambolic, I., Apostolovic, D., Milcic, M., Stanic-Vucinic, D., and Cirkovic Velickovic, T. (2015). Complexes of green tea polyphenol, epigalocatechin-3-gallate, and $2 \mathrm{~S}$ albumins of peanut. Food Chem. 185, 309-317. doi: 10.1016/j.foodchem.2015.04.001

Vieira da Silva, B., Barreira, J. C. M., and Oliveira, M. B. P. P. (2016). Natural phytochemicals and probiotics as bioactive ingredients for functional foods: extraction, biochemistry and protected-delivery technologies. Trends Food Sci. Technol. 50, 144-158. doi: 10.1016/j.tifs.2015.12.007

Vuolo, M. M., Lima, V. S., and Maróstica Junior, M. R. (2018). Phenolic Compounds: Structure, Classification, and Antioxidant Power. Amsterdam: Elsevier Inc. doi: 10.1016/B978-0-12-814774-0.00002-5

Vuolo, M. M., Lima, V. S., Roberto, M., and Junior, M. (2019). Classification, and Antioxidant Power. Bioactive Comp. 2019, 33-50.

Wang, Q., Shi, A., Liu, H., Liu, L., Zhang, Y., Li, N., et al. (2016). "Peanut by-products utilization technology," in Peanuts: Processing Technology and Product Development (Academic Press), 211-325. doi: 10.1016/B978-0-12-809595-9.00005-3 
Wang, X., Zhang, J., Lei, F., Liang, C., Yuan, F., and Gao, Y. (2014). Covalent complexation and functional evaluation of (-)-epigallocatechin gallate and $\alpha$-lactalbumin. Food Chem. 150, 341-347. doi: 10.1016/j.foodchem.2013.09.127

Yang, M., Sun, J., Lu, Z., Chen, G., Guan, S., Liu, X., et al. (2009). Phytochemical analysis of traditional Chinese medicine using liquid chromatography coupled with mass spectrometry. J. Chromatograp. A 1216, 2045-2062. doi: 10.1016/j.chroma.2008.08.097

Ye, Q., Wang, H., and Xu, J. (2015). Application of NMR Spectroscopy for the Characterization of Dietary Polyphenols. Amsterdam: Elsevier Ltd. doi: 10.2174/9781681080628115030004

Yilmaz, E. E., Özvural, E. B., and Vural, H. (2011). Extraction and identification of proanthocyanidins from grape seed (Vitis Vinifera) using supercritical carbon dioxide. J. Supercrit. Fluids 55, 924-928. doi: 10.1016/j.supflu.2010.10.046

Yousef, M., Crozier, R. W. E., Hicks, N. J., Watson, C. J. F., Boyd, T., Tsiani, E., et al. (2020). Attenuation of allergen-mediated mast cell activation by rosemary extract (Rosmarinus officinalis L.). J. Leukoc. Biol. doi: 10.1002/JLB.3A0320-434R

Yu, L., Meng, Y., Wang, Z., Cao, L., Liu, C., Gao, Z., et al. (2020). Sustainable and efficient surfactant-based microwave-assisted extraction of target polyphenols and furanocoumarins from fig (Ficus carica L.) leaves. J. Mol. Liquids 318:114196. doi: 10.1016/j.molliq.2020.114196

Yu, W., Freeland, D. M. H., and Nadeau, K. C. (2016). Food allergy: immune mechanisms, diagnosis and immunotherapy. Nat. Rev. Immunol. 16, 751-765. doi: $10.1038 /$ nri.2016.111

Zeyada, N. N., Zeitoum, M. A. M., and Barbary, O. M. (2008). Utilization of some vegetables and fruit waste as natural antioxidants. Alex. J. Food Sci. Technol. 5, 1-11. doi: 10.21608/ajfs.2008.20136

Zhou, Z., Shi, T., Hou, J., and Li, M. (2020). Ferulic acid alleviates atopic dermatitis-like symptoms in mice via its potent anti-inflammatory effect. Immunopharmacol. Immunotoxicol. 42, 156-164. doi: 10.1080/08923973.2020.1733012

Zhu, F. (2017). Coix: Chemical composition and health effects. Trends Food Sci. Technol. 61, 160-175. doi: 10.1016/j.tifs.2016.12.003

Zhu, Z., Gavahian, M., Barba, F. J., Roselló-Soto, E., Kovačević, D. B., Putnik, P., et al. (2020). "Valorization of waste and by-products from food industries through the use of innovative technologies," in Agri-Food Industry Strategies for Healthy Diets and Sustainability (Academic Press), 249-266. doi: 10.1016/B978-0-12-817226-1.00011-4

Zuercher, A., Holvoet, S., Weiss, M., and Mercenier, A. (2010). Polyphenol-enriched apple extract attenuates food allergy in mice. Clin. Experi. Allergy 40, 942-950. doi: 10.1111/j.1365-2222.2010.0 3460. $\mathrm{x}$

Zuin, V. G., and Ramin, L. Z. (2018). Green and Sustainable Separation of Natural Products from Agro - Industrial Waste: Challenges, Potentialities, and Perspectives on Emerging Approaches. Topics Curr. Chem. 376:3. doi: $10.1007 / \mathrm{s} 41061-017-0182-\mathrm{z}$

Conflict of Interest: The authors declare that the research was conducted in the absence of any commercial or financial relationships that could be construed as a potential conflict of interest.

Copyright (C) 2021 Bessa, Francisco, Dias, Mateus, Freitas and Pérez-Gregorio. This is an open-access article distributed under the terms of the Creative Commons Attribution License (CC BY). The use, distribution or reproduction in other forums is permitted, provided the original author(s) and the copyright owner(s) are credited and that the original publication in this journal is cited, in accordance with accepted academic practice. No use, distribution or reproduction is permitted which does not comply with these terms. 